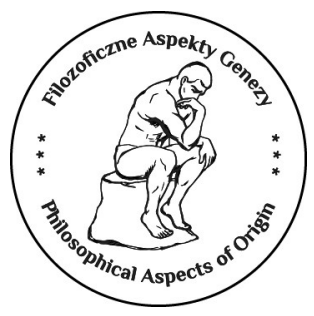

Filozoficzne Aspekty Genezy — 2019/2020, t. 16/17

Philosophical Aspects of Origin

\title{
Aktualność arystotelizmu w kontekście poszukiwań ontologicznego fundamentu informacji biologicznej
}

\section{Wstęp}

Wraz z pojawieniem się empirycznej teorii wiedzy we wczesnej filozofii nowożytnej, rozwojem matematycznych teorii informacji w dwudziestym wieku oraz rozwojem technologii informacyjnej, pojęcie ,informacji” zajęło centralne miejsce w nauce i kulturze. Zainteresowanie fenomenem informacji doprowadziło również do powstania odrębnej gałęzi filozofii, która analizuje informację we wszystkich jej postaciach, $\mathrm{w}$ aspektach logicznym, epistemologicznym, ontologicznym, etycznym i estetycznym. I choć może się to wydać paradoksalne, filozofia informacji pomogła nam uświadomić sobie, jak trudno jest wypracować jednoznacznie uzgodnioną i ściśle naukową definicję informacji.

Ta sama trudność dotyczy pojęcia informacji biologicznej, tj. informacji, która jest zapisywana, odczytywana oraz znajduje swoją ekspresję w systemach (bytach) ożywionych. Pomimo powszechności terminologii informacyjnej w języku biologii (gen jako nośnik informacji, ekspresja, transkrypcja, translacja, edytowanie genów, programy rozwojowe i tym podobne), także $w$ tej dziedzinie badań nad informacją nie jest łatwo sformułować jej precyzyjną definicję. Jednocześnie, niebywały sukces paradygmatu i metodologii biologii molekularnej i genetyki, doprowadził do genocentryzmu, który podniósł geny (rozumiane jako nośniki informacji biologicznej) do rangi podstawowych jednostek biologicznych, podlegających działaniu doboru naturalnego i ewolucji.

Dr Mariusz TABaczeK — Pontifical University of Saint Thomas Aquinas, e-mail: mtabaczek@gmail. com. 
Niniejszy artykuł ukazuje drogę od zakwestionowania genocentryzmu do wieloaspektowego ujęcia informacji biologicznej na tle historycznego rozwoju oraz aktualnego stanu badań filozoficznych nad istotą informacji w ujęciu ogólnym. W centrum rozważań znajduje się ontyczny aspekt informacji biologicznej oraz argument na rzecz aktualności kluczowych kategorii filozofii przyrody Arystotelesa jako fundamentalnych dla rozumienia i definiowania aspektów ilościowego, jakościowego, strukturalnego, „teleosemantycznego" (,teleofunkcjonalistycznego”), interakcyjnego oraz relacyjnego (,komunikatywistycznego") informacji zapisanej i znajdującej wyraz w funkcjonowaniu systemów (bytów) ożywionych.

\section{Krytyka paradygmatu genocentrycznego}

Jak zauważa Anna Marek-Bieniasz, genocentryzm, w ramach którego zakłada się, iż dobór naturalny działa na poziomie genów (nie na poziomie osobników, czy też grup osobników), został najprawdopodobniej wyartykułowany po raz pierwszy przez Williama D. Hamiltona (1964) i George'a C. Williamsa (1966). ${ }^{1}$ Do ugruntowania się poglądu, że na ewolucję najlepiej patrzeć, uznając, iż dobór naturalny działa na poziome genów, przyczyniły się zwłaszcza poglądy Williamsa, który w innym miejscu stwierdził, że: „Podstawowe pytania ewolucyjne mogą doczekać się odpowiedzi tylko wtedy, gdy przyjmiemy, że każdy gen jest w konflikcie z każdym innym genem, nawet z tymi zajmującymi inne loci $\mathrm{w}$ tej samej komórce. $\mathrm{W}$ pełni trafna teoria doboru naturalnego musi być ostatecznie oparta na samolubnych replikatorach, genach i innych jednostkach posiadających zdolność zróżnicowanego gromadzenia się w swych odmiennych formach wariantowych". ${ }^{2}$

Aleksander Ziemny słusznie zauważa, że zwrot genocentryczny w biologii dwudziestego wieku miał wpływ zarówno na biologię ewolucyjną, jak i biologię rozwoju, które w tym samym czasie - także w kontekście rozwoju genetyki — zaczęto traktować jako osobne działy nauki o życiu. ${ }^{3}$ Apogeum genocentryzmu w najnowszej biolo-

\footnotetext{
${ }^{1}$ Por. Anna MAREK-BienIasz, „Genocentryczny paradygmat rozumienia przyrody i jego zasadność w R. Dawkinsa interpretacji ewolucji”, Studia Philosophiae Christianae 2009, t. 45, nr 1, s. 163 [163178]; W. Hamilton, „The Genetical Evolution of Social Behaviour I-II”, Journal of Theoretical Biology 1964, vol. 7, no. 1, s. 1-52; George C. Williams, Adaptation and Natural Selection, Princeton University Press, Princeton 1966.

${ }^{2}$ George C. Williams, „The Question of Adaptive Sex Ratio in Outcrossed Vertebrates”, Proceedings of the Royal Society of London B 1979, vol. 205, s. 567 [567-580].

${ }^{3}$ Źródeł genocentryzmu można upatrywać (1) w postulacie A. Weismanna odnośnie istnienia dwóch odrębnych linii komórkowych (somatycznych oraz generatywnych, gdzie wszelka zmiana dziedziczna ma miejsce w komórkach generatywnych), (2) w rozwoju genetyki populacyjnej (wraz z wprowadzeniem przez Wilhelma Johannsena pojęć genu, genotypu i fenotypu), (3) w odkryciu struktury DNA i sformułowaniu przez Francisa Cricka centralnego dogmatu genetyki molekularnej, oraz (4) we wskazaniu przez
} 
gii ewolucyjnej znajduje wyraz w metaforyce stosowanej przez Richarda Dawkinsa. Uczony ten dochodzi do wniosku, że podstawową jednostką biologiczną podlegającą ewolucji są nie tyle organizmy żywe, co informacja, zapisana w genach, które „podróżują" w czasie i przestrzeni w tychże organizmach. ${ }^{4}$ Jego poglądy wpisują się w retorykę, w ramach której „DNA urasta do rangi causa prima żywego organizmu". W przypadku embriologii genocentryzm przejawia się w przesadnym akcentowaniu, skądinąd realnego i istotnego, wpływu — wspólnych wielu organizmom - genów homeotycznych (tak zwane hox genes lub homeobox genes) na kluczowe fazy rozwoju zarodków. ${ }^{6}$

Genocentryzm spotkał się z krytyką ze strony wielu biologów i filozofów biologii. Jednym z jego kluczowych założeń było przypisywanie DNA dwóch właściwości, którymi są (1) zdolność do replikacji samego siebie oraz (2) zdolność do budowania innych biomolekuł. Aczkolwiek powszechne, przekonanie o prawdziwości tych dwóch tez jest błędne. Odnośnie do (1) Piotr Lenartowicz mówi o „micie samopowielania (autoreplikacji)” bądź też o „micie autokatalizy”, który upadł wraz z odkryciem tego,

Thomasa H. Morgana mechanizmów dziedziczenia. Por. Aleksander ZIEMNY, „Spór o genocentryzm w filozofii biologii”, Studia Philosophiae Christianae 2017, t. 53, nr 1, s. 145-149 [146-168].

${ }^{4} \mathrm{~W}$ trzecim rozdziale swojej książki Samolubny gen Dawkins stwierdza: „Innym aspektem niepodzielności genu jest to, że się nie starzeje. Prawdopodobieństwo jego śmierci nie zależy od tego, czy jego wiek liczy się w milionach, czy tylko w setkach lat. Przeskakuje z ciała do ciała w łańcuchu pokoleń, zręcznie kierując kolejnymi ciałami, stosując właściwe sobie metody i osiagając własne korzyści, porzucając schedę śmiertelnych ciał, nim te pogrążą się w starości i śmierci. Geny są nieśmiertelne, a przynaj mniej - można rzec - zasługuja na to miano" (Richard Dawkins, Samolubny gen, przeł. Marek Skoneczny, Prószyński i S-ka, Warszawa 1996, s. 59). Podzielając tezę Richarda Alexandra, który stwierdza, że ,geny sa najbardziej trwałymi spośród wszystkich jednostek składowych organizmów żywych, a przez to także najbardziej podstawowymi jednostkami podlegającymi selekcji”, Dawkins sugeruje, że ewolucja jest ostatecznie zmaganiem linii genetycznych o przetrwanie i replikację, podczas gdy organizmy i fenoty py są zaledwie manifestacjami genów. Dawkins nazywa je wręcz maszynami przechowującymi geny. Por Richard D. Alexander, Darwinism and Human Affairs, University of Washington Press, Seattle 1979, s. 3

${ }^{5}$ Radosław SiedliŃski, „Genocentryzm versus teoria systemów rozwojowych. Dwa konkurencyjne sposoby rozumienia informacji w biologii współczesnej”, Semina Scientiarum 2018, t. 16, s. 71 [67-93] Siedliński powołuje się na komentarz filozofa biologii Davida Hulla, który twierdzi, że za wyjątkiem transmisji kulturowej u niektórych gatunków zwierząt geny są jedyną przyczyną istnienia uporządkowanych struktur w świecie istot żywych (por. Kim Sterelny, Kelly C. Smith, and Michael Dickson, „The Extended Replicator", Biology and Philosophy 1996, vol. 11, s. 380 [377-403]).

${ }^{6}$ Ziemny sugeruje, aby odróżnić genocentryzm od determinizmu genetycznego. Twierdzi, że ten ostatni ma charakter czysto redukcjonistyczny (zakładając, że określone, często złożone, cechy fenotypowe są w pełni determinowane przez genom), podczas gdy zwolennicy genocentryzmu ,nie negują istotności procesów pozagenetycznych, jedynie wyróżniają elementy DNA”. Jednocześnie przyznaje, że genocentryzm jest formą redukcjonizmu molekularnego, który definiuje jako wymaganie „aby wyjaśnienia dowolnego zjawiska biologicznego odwoływały się do opisu molekularnego” (ZiEMNY, „Spór o genocentryzm...", s. 151-153). 
że „liczba wszystkich różnorodnych czynników, które współdziałają w operacji powielenia cząsteczki DNA i które są absolutnie niezastąpione, przekroczyła już liczbę stu". Co więcej „Proces replikacji DNA jest ściśle zsynchronizowany z aktualnym stanem innych mechanizmów wewnątrzkomórkowych, z parametrami środowiska i sygnałami, które stamtąd do komórki dochodzą". ${ }^{7}$ Podobnie jest w przypadku tezy (2), którą Lenartowicz określa jako „mit heterokatalizy czyli kierowniczej roli DNA”. ${ }^{8}$ Mit ten podważają odkrycia genetyki molekularnej, która dotyczy nie tylko przyczynowego wpływu genów na rozwój osobniczy (embriologia), lecz także działania molekularnych mechanizmów ewolucyjnych. To właśnie ten dział biologii wskazuje na konieczność właściwego podejścia interpretacyjnego do materiału genetycznego, które można określić mianem „kontekstualizacji DNA”. ${ }^{9}$

\section{Kontekstualizacja DNA}

Jedno z najbardziej spektakularnych odkryć w historii nauki, to jest poznanie struktury (Rosalind Franklin i Maurice Wilkins — lata 1951-1952) oraz opracowanie modelu DNA (James Watson i Francis Crick - rok 1953), dało początek dalszym szczegółowym badaniom mającym na celu poznanie roli i funkcjonowania materiału genetycznego w rozwoju i ewolucji organizmów żywych. ${ }^{10} \mathrm{~W}$ ramach tych badań dokonano odkrycia, które stało się jednym z pierwszych kroków na drodze prowadzącej do zakwestionowania genocentryzmu. Chodzi o osobliwą właściwość DNA, którą Richard Lewontin (słynny genetyk z Harwardu) oraz Richard Levins (specjalista w dziedzinie nauk populacyjnych z Harwardu) opisują na konkretnym przykładzie sekwencji nukleotydów G-T-A-A-G-T. Zazwyczaj komórkowa maszyneria odczytująca treść kodu DNA i „przepisująca” lub „realizująca” go w postaci konkretnego kształtu syntezowanego białka, odczytuje sekwencję G-T-A-A-G-T jako dwukodonową instrukcję dołączenia do rosnącego łańcucha białkowego dwóch aminokwasów: waliny i seryny. Oka-

\footnotetext{
${ }^{7}$ Piotr Lenartowicz, „Mitologia programu genetycznego DNA”, w: Jolanta Koszteyn (red.) Vivere et Intelligere. Wybrane prace Piotra Lenartowicza SJ wydane z okazji 75-lecia jego urodzin, WAM, Kraków 2009, s. 101, 103-105 [101-114].

${ }^{8}$ Lenartowicz, „Mitologia programu genetycznego DNA...”, s. 105-108.

${ }^{9}$ Por. też Richard Lewontin, It Ain't Necessarily So: The Dream of the Human Genome and Other Illusions, New York Review Books, New York 2001, s. 137-141; SiedLiŃski, „Genocentryzm...”, s. $79-82$.

${ }^{10}$ DNA zostało odkryte już w 1869 roku przez szwedzkiego fizyka Fryderyka Mieschera, jednak jego struktura przez prawie 100 lat pozostawała nieznana ze względu na ograniczoność technik i instrumentów badawczych. Kolejnym krokiem było złamanie kodu DNA, a więc języka, w jakim zapisana jest w nim informacja, a następnie mapowanie genomu (informacji genetycznej) wielu organizmów żywych, w tym także człowieka. Projekt ten, rozpoczęty w roku 1990, zakończył się sukcesem w roku 2003, por. http:// web.ornl.gov/sci/techresources/Human_Genome/index.shtml [08.10.2020].
} 
zuje się jednak, że w pewnych przypadkach ta sama sekwencja G-T-A-A-G-T bywa odczytana jako sekwencja, która nie tyle dyktuje kształt nowego białka, co reguluje ekspresję całego sąsiedniego genu w łańcuchu DNA. W innych przypadkach sekwencja ta spełnia funkcję krótkiego, niekodującego odcinka DNA, oddzielającego dwa sąsiednie geny. ${ }^{11}$ Przykład ten wskazuje na to, że — jak stwierdza neurobiolog Jonah Lehrer — „DNA jest zdefiniowany przez wielość możliwych znaczeń; jest kodem, który wymaga kontekstu". ${ }^{12}$ Ta sama sekwencja nukleotydów może mieć zupełnie inne znaczenie w zależności od swojego sąsiedztwa w łańcuchu DNA. A zatem, charakter informacji zawartej w danym fragmencie DNA wymaga odczytywania jej w szerszym kontekście całej cząsteczki DNA. Można powiedzieć, że fakt ten określa pierwszy stopień kontekstualizacji DNA.

Ale to jeszcze nie wszystko. Szersze ujęcie roli i funkcji pojedynczych kodonów DNA każe nam wziąć pod uwagę nie tylko całą cząsteczkę DNA, lecz także maszynerię komórkową zaangażowaną w odczytywanie i „tłumaczenie” informacji zawartej w DNA na ,język" aminokwasów w białkach. W skład tej maszynerii wchodzą nie tylko konkretne organelle komórkowe — rybosomy, które są fabrykami białek — ale także cały szereg biomolekuł pełniących różnorodne funkcje $\mathrm{w}$ procesie transkrypcji i translacji DNA, zlokalizowanych w bardzo konkretnych przedziałach jądra komórkowego, błony jądrowej oraz w przestrzeni pomiędzy jądrem komórkowym a rybosomami. Poza kontekstem maszynerii komórkowej tłumaczącej język DNA na język białek, DNA jest „martwym” związkiem chemicznym, niezdolnym do żadnej aktywności. Zawarta w nim informacja jest niejako „uwięziona”, to znaczy jej zdolność informowania nowego nośnika jest jak gdyby „W zawieszeniu”. Jest to drugi stopień kontekstualizacji DNA.

Idąc jeszcze dalej, nasza analiza DNA wymaga dodatkowych uzupełnień. Okazuje się bowiem, że choć wszystkie komórki złożonego organizmu zawierają to samo DNA, ekspresja tego ostatniego przebiega różnie i ma różne skutki w różnych częściach i na różnych etapach rozwoju danego organizmu, pozostającego w unikalnej relacji do środowiska, w którym żyje. Jednym z ważniejszych odkryć embriologii sprzed ponad trzydziestu lat było zwrócenie uwagi na to, że komórki organizmu zwierzęcego w pierwszych dniach od zapłodnienia mają totipotencjalny charakter — to znaczy każda z nich może przekształcić się we wszelkie możliwe typy komórek somatycznych da-

\footnotetext{
${ }^{11}$ Por. Richard Lewontin and Richard Levins, Biology Under the Influence: Dialectical Essays on the Coevolution of Nature and Society, NYU Press, New York 2007, s. 245.

${ }^{12}$ Jonah Lehrer, Proust Was a Neuroscientist, Houghton Mifflin Company, Boston, New York 2007, s. 45
} 
nego organizmu. To cecha, której nie posiadają komórki dojrzałego organizmu. ${ }^{13}$ Fakt ten wskazuje na to, że charakter ekspresji pojedynczych kodonów DNA zależy nie tylko od treści większego fragmentu DNA, którego są one częścią, oraz maszynerii transkrypcji i translacji - przepisującej informację z DNA na konstrukcję białek - lecz także od charakteru całego organizmu w relacji do środowiska naturalnego oraz etapu rozwoju, na którym się znajduje. Jest to trzeci i najwyższy stopień kontekstualizacji DNA. ${ }^{14}$

\section{Epigenetyka, biologia systemów, systemowa teoria rozwoju i evo-devo}

Kolejnym argumentem wskazującym na konieczność szerokiej kontekstualizacji analitycznego badania biomolekuł w ramach genetyki molekularnej jest jedna $\mathrm{z}$ najnowszych szczegółowych dziedzin biologii, określana mianem „epigenetyki”. Nauka ta zajmuje się badaniem cech i zmian, które - jak się okazuje — są trwałe i dziedziczne, nie będąc jednocześnie rezultatem zmian w strukturze DNA — stąd nazwa epigenety$\mathrm{ka}$, to jest nauka badająca trwałe i dziedziczne zmiany ponad, czy poza tymi, które są zakorzenione w genomie. Przykładem może być metylacja, fosforylacja lub acetylacja białek histonowych wchodzących w skład chromatyny, będąca źródłem zmian w ekspresji genów nie związanych ze zmianami w samym DNA. Fakt ten poddaje w wątpliwość zasadność genocentryzmu w biologii. Podważa tezę, w myśl której materiał genetyczny jest jedynym nośnikiem informacji dziedzicznej oraz podstawą wyjaśniania wszelkich zjawisk biologicznych. ${ }^{15}$

Świadomość konieczności kontekstualizacji DNA, wsparta dynamicznym rozwojem komputerowych technik gromadzenia i analizy danych (tak zwana big data science), stała się źródłem radykalnej zmiany perspektywy w biologii molekularnej, polegającej na przejściu od badania biomolekuł pojedynczo lub w małych grupach oraz in vitro, to jest pozaustrojowo, do analizy ich zachowania in vivo, czyli wewnątrz organizmu. To nowe stanowisko metodologiczne w biologii jest określane mianem „systemowego" (biologia systemów). W pewnym sensie jest ono przejściem od poziomu mikro analizy biologicznej z powrotem do poziomu makro spojrzenia na organizmy, bez pod-

\footnotetext{
${ }^{13}$ Piotr Lenartowicz, „Totipotencjalność — kluczowe pojęcie biologii rozwoju”, w: Koszteyn (red.) Vivere et Intelligere..., s. 145-162 [145-171].

${ }^{14}$ Por. Gerard M. Verschuuren, Aquinas and Modern Science: A New Synthesis of Faith and Reason, Angelico Press, Kettering 2016.

${ }^{15}$ Por. Renato Paro, Ueli Grossniklaus, Raffaella Santoro, and Anton Wutz, Introduction to Epigenetics, Springer, Berlin 2021; C. David Aldis, Marie-Laure Caparros, Thomas Jenuwein, and Danny Reinberg (eds.) Epigenetics, 2nd ed., Cold Spring Harbor, New York 2015; Andrzej T. Wierzbicki, „Dziedziczenie epigenetyczne”, Kosmos 2004, t. 53, nr 3-4, s. 271-280.
} 
ważania znaczenia reduktywnego aspektu metodologii biologii molekularnej, biochemii i genetyki. ${ }^{16}$

Ten sam nurt powrotu do bardziej holistycznego spojrzenia na organizmy żywe zaowocował także nowym podejściem w embriologii. W miejsce genocentryzmu zasugerowano tezę parytetu przyczynowego (causal democracy thesis), zakładającego szerszą perspektywę w przyczynowej analizie zmian rozwojowych. ${ }^{17} \mathrm{Na}$ bazie tej tezy rozwinęła się systemowa teoria rozwoju (developmental system theory), która argumentuje na rzecz pluralizmu bądź holizmu w ujęciu systemów dziedziczenia. ${ }^{18}$

W ramach stanowiska pluralistycznego Eva Jablonka i Marion Lamb postulują, aby obok systemów dziedziczenia genetycznego (genetic inheritance system) oraz epigenetycznego (epigenetic inheritance system) wprowadzić kategorie systemów dziedziczenia behawioru (behavioral inheritance system) oraz dziedziczenia symbolicznego (dziedziczenia języków) (symbolic inheritance system). ${ }^{19}$ Heikki Helanterä i Tobias Uller proponują jeszcze inny podział na: (1) system dziedziczenia wertykalnego (vertical inheritance), obejmujący klasyczne międzypokoleniowe dziedziczenie genetyczne i epigenetyczne, (2) system dziedziczenia indukowanego (induction), kładący nacisk na różnicowanie (modyfikację) cech w relacji przodek-potomek oraz (3) system dziedziczenia przez nabycie (acquisition), biorący pod uwagę sposoby nabywania cech na drodze innej niż w relacji przodek-potomek, na przykład horyzontalny transfer genów u bakterii czy różne formy uczenia się chociażby języka. ${ }^{20}$

\footnotetext{
${ }^{16}$ Por. Eberhad O. VorT, A First Course in Systems Biology, Garland Science, New York and London 2013, rozdz. 1, s. 1-17; Constantinos Mekios, ,Explanation in Systems Biology: Is It All About Mechanisms?", w: Pierre-Alain Braillard and Christophe Malaterre (eds.), Explanation in Biology: An Enquiry into the Diversity of Explanatory Patterns in the Life Sciences, Springer, Dordrecht 2015, s. 4772; Fred Boogerd, Frank J. Bruggeman, Jan-Hendrik S. Hofmeyr, and Hans V. Westerhoff (eds.), Systems Biology: Philosophical Foundations, Elsevier, Amsterdam 2007; Sara Green, „Philosophy of Systems and Synthetic Biology”, w: Edward N. Zalta (ed.), The Stanford Encyclopedia of Philosophy (Winter 2017 Edition), https://plato.stanford.edu/archives/win2017/entries/systems-synthetic-biology/ [08.10. 2020]; Sara Green (ed.), Philosophy of Systems Biology: Perspectives from Scientists and Philosophers, Springer, Copenhagen 2017.

${ }^{17}$ Por. Susan Oyama, „Causal Democracy and Causal Contributions in Developmental Systems Theory”, Philosophy of Science 2000, vol. 67, s. S332-S347.

${ }^{18}$ Por. Siedliński, „Genocentryzm...”, s. 82-87.

${ }^{19}$ Por. Eva Jablonka and Marion J. Lamb, Evolution in Four Dimensions, MIT Press, Cambridge, Massachusetts 2005; Eva JABLONKA, „Genes as Followers in Evolution - A Post-Synthesis Synthesis?”, Biology and Philosophy 2010, vol. 21, no. 1, s. 143-154.

${ }^{20}$ Heikki Helanterä and Tobias Uller, „The Price Equation and Extended Inheritance”, Philosophy and Theory in Biology 2010, vol. 2, no. 1, s. 9 [1-17]. Por. też Aleksander ZIEMnY, „Natura dziedziczenia”, w: Krzysztof Chodasewicz, Adrianna Grabizna, Agnieszka Proszewska, Adrian Stencel i Aleksander ZIEMNY (red.), Glówne problemy filozofii biologii, IFiS PAN, Warszawa 2017, s. 84-87.
} 
Z kolei podejście holistyczne cechuje generalny sceptycyzm wobec rozróżniania systemów dziedziczenia. Proces rozwoju jest tu postrzegany jako interakcja i transformacja różnych struktur genetycznych i epigenetycznych, czemu towarzyszy także emergencja zupełnie nowych fenomenów. Ziemny ${ }^{21}$ tak podsumowuje poglądy Susan Oyama, Paula Griffithsa oraz Russella D. Graya w tej kwestii: ${ }^{22}$

1. Istnieje wiele niezależnych przyczyn działających wspólnie na rozwijający się organizm, zaś czynniki genetyczne i środowiskowe to wyłącznie jedna z możliwości ich ujęcia;

2. Istotny jest kontekst i stan układu, gdyż każda z przyczyn jest uwarunkowana stanem całego układu;

3. Konieczne jest rozszerzenie pojęcia dziedziczności, które odnieść należy do szerokiego wachlarza zasobów wpływających na cykl życiowy organizmu;

4. Rozwój należy postrzegać jako rekonstrukcję, ponieważ ani cechy, ani reprezentacje tych cech (w kodzie DNA) nie są przekazywane potomstwu, lecz cechy (w szerokim sensie) są rekonstruowane podczas rozwoju potomstwa;

5. Proces rozwoju nie odbywa się za pośrednictwem jakiegoś głównego czynnika (genów), lecz kontrola rozwoju rozproszona jest w ramach wielu układów również niegenetycznych — rzecz w tym, aby te układy traktować jako całościowy system;

6. Ewolucję należy rozpatrywać jako system oddziałujących wzajemnie na siebie organizmów i środowiska.

Oczywiście, tak szerokie ujęcie mechanizmów mających wpływ na jednostkowy rozwój organizmu, natrafia na niełatwe wyzwanie w postaci konieczności określenia kryterium ograniczającego zakres badanego układu. Jednocześnie, pluralizm i holizm w kwestii systemów dziedziczenia, znajdują kontynuację w ewolucyjnej biologii rozwoju (evolutionary developmental biology - evo-devo), która na nowo wiąże ze sobą biologię ewolucyjną oraz biologię rozwoju. Jej zasadnicze założenia zamykają się w: (1) postulacie uznania hierarchicznej struktury zarówno dziedziczenia, jak i ewolucji (w skali mikro i makro), (2) postulacie koncentracji badań nad zależnością między genotypem i (szeroko pojętym) fenotypem oraz (3) uznaniu, że poznanie procesów roz-

\footnotetext{
${ }^{21}$ Por. Ziemny, „Natura dziedziczenia...”, s. 88.

${ }^{22}$ Por. Susan Oyama, Paul E. Griffiths, and Russell D. Gray, „Introduction: What Is Developmental Systems Theory?”, w: Susan Oyama, Paul E. Griffiths, and Richard D. Gray (eds.), Cycles of Contingency: Developmental Systems and Evolution, The MIT Press, Cambridge, Massachusetts 2001, s. 1-12.
} 
wojowych wraz z ich mechanizmami i ewolucją poszerza naszą wiedzę z zakresu biologii rozwoju i biologii ewolucyjnej. ${ }^{23}$

\section{Odejście od genocentryzmu w świetle rozumienia informacji biologicznej}

Odejście od genocentryzmu w biologii ewolucyjnej i biologii rozwoju znajduje odzwierciedlenie w bardziej teoretycznej (filozoficznej) próbie definicji oraz analizy informacji biologicznej. Peter Godfrey-Smith i Kim Sterelny zwracają uwagę na to, że zainteresowanie informacją we współczesnej biologii wychodzi daleko poza oczywiste zastosowanie w analizie biologicznych aspektów percepcji, poznania czy języka. ${ }^{24} \mathrm{Po}-$ jęcie informacji pojawia się w definiowaniu istoty oraz opisie roli genów (gen jako nośnik informacji, ekspresja, transkrypcja, translacja, edytowanie genów), w analizie funkcji biomolekuł (np. definiowanie hormonów jako sygnałów), w analizie „losu” komórek w rozwijającym się organizmie (informacja pozycjonująca pochodząca z sąsiednich komórek oraz innych czynników), w rozumieniu procesów rozwojowych (pojęcie programu rozwojowego), czy wreszcie w kontekście biologii ewolucyjnej (zależność przełomowych zmian od dokładności przekazu informacji genetycznej między pokoleniami). Ocena zasadności użycia tego typu terminologii na gruncie nauk biologicznych wymaga odpowiedzi na pytanie o to, czym jest informacja w ogólności oraz czym jest informacja biologiczna.

\section{Wspólczesna analiza informacji}

Chociaż historia samego terminu ,informacja” sięga wstecz do starożytnej Grecji, filozofia informacji jako odrębna dziedzina wiedzy wyłoniła się stosunkowo niedawno. Kontekstem jej powstania były początki empirycznej teorii wiedzy w nowożytności

\footnotetext{
${ }^{23}$ Por. Jason S. Roвert, „How Developmental Is Evolutionary Developmental Biology?”, Biology and Philosophy 2002, vol. 17, s. 591-611; Jason S. RoBert, „Developmental Systems and Animal Behaviour”, Biology and Philosophy 2003, vol. 18, s. 477-489. Istotną konsekwencją odejścia od genocentryzmu jest także nowa linia badań i hipotez dotyczących początku życia na Ziemi. W dziedzinie tej obserwujemy przejście, przynajmniej części badaczy, od założenia mówiącego, że kwas nukleinowy — DNA bądź RNA - jest warunkiem sine qua non istnienia życia, do hipotezy powstania pierwszych systemów ożywionych i multiplikujących się niezależnie od / pod nieobecność kwasów nukleinowych na podstawie informacji zapisanej i przekazywanej w formie konkretnej organizacji danego systemu biochemicznego. Prominentnym przedstawicielem tego nurtu jest Terrence Deacon z Uniwersytetu w Berkeley. Por. Terrence W. Deacon, ,Reciprocal Linkage Between Self-Organizing Processes Is Sufficient for Self-Reproduction and Evolvability”, Biological Theory 2006, vol. 1, s. 136-149.

${ }^{24}$ Por. Peter Godfrey-Smith and Kim Sterelny, „Biological Information”, w: Edward N. Zalta (ed.), The Stanford Encyclopedia of Philosophy (Summer 2016 Edition), https://plato.stanford.edu/archives/ sum2016/entries/information-biological/ [08.10.2020].
} 
oraz rozwój matematycznych koncepcji informacji i związanych z nimi nowych technologii informacyjnych w XX wieku. ${ }^{25}$

Pierwszym wyzwaniem dla filozofii informacji jest sama jej definicja. ${ }^{26}$ Potoczne rozumienie terminu ,informacja” jako odpowiednika dowolnej miary danych, kodu lub tekstu - zapisanego, wysyłanego, odbieranego, lub manipulowanego w postaci dowolnego rodzaju medium - wydaje się być wysoce niewystarczające. Próba ujęcia istoty „informacji” na meta poziomie analizy zrodziła szereg definicji. Część z nich kładzie nacisk na ilościowy (pojemnościowy) aspekt informacji, definiując ją jako komunikację lub łączność „likwidującą nieokreśloność”, identyfikującą „brakujące elementy” czy też zmniejszającą entropię (gdzie entropia jest postrzegana jako miara brakującej informacji o stanie układu fizycznego). Ich autorami są, między innymi R.V.L. Hartley, R.A. Fisher, C.E. Shannon, N. Wiener czy A.N. Kolmogorov. M. Lubański słusznie zauważa, że ujęcie to de facto „nie zajmuje się zagadnieniem, czym jest informacja, a jedynie podaje sposoby mierzenia ilości informacji i to w tym tylko przypadku, kiedy mamy do czynienia z pełnym układem prawdopodobieństw. Toteż bardziej adekwatną nazwą omawianej koncepcji byłaby ilościowa teoria informacji $\mathrm{w}$ aspekcie probabilistycznym". ${ }^{27}$

Druga grupa klasycznych ponowożytnych definicji informacji kładzie nacisk na jej jakościowy charakter. Przykładem może być teoria informacji jako stanu podmiotu (stanowisko proponowane przez J. Hintikka czy F. Dretske), czy teoria semantyczna Y. Bar-Hillela i R. Carnapa. ${ }^{28} \mathrm{~W}$ myśl tej ostatniej informacja jest zdefiniowana przez L. Floridiego jako właściwie ukształtowana, posiadająca znaczenie i wiarygodna dana. Istotnym aspektem tych definicji staje się możliwość wartościowania informacji na podstawie tego, w jakim stopniu służy ona zamierzonemu celowi. To z kolei zwraca naszą uwagę na rolę procesualnego czy też transformacyjnego aspektu informacji rozumianej jako odwzorowanie określonego stanu fizycznego w ramach oddziaływania jednego systemu na drugi.

\footnotetext{
${ }^{25}$ Por. Luciano Floridi, The Philosophy of Information, Oxford University Press, Oxford 2011.

${ }^{26}$ Por. P. Adrians, „Information”, w: Edward N. Zalta (ed.), The Stanford Encyclopedia of Philosophy (Fall 2020 Edition), https://plato.stanford.edu/archives/fall2020/entries/information/ [08.10.2020]; Witold NawrockI, „W poszukiwaniu istoty informacji”, w: Jacek Juliusz JADACKI (red.), Analiza pojęcia informacji, Wydawnictwo Naukowe Semper, Warszawa 2003, s. 41-50 [37-62].

${ }^{27}$ Mieczysław Lubaśski, „O pojęciu informacji”, Studia Philosophiae Christianae 1974, t. 10, nr 1, s. 74 [73-99].

${ }^{28}$ Por. Jaakko HintiKKa, Knowledge and Belief: An Introduction to the Logic of the Two Notions, Cornell University Press, Ithaca 1962; Fred DreTSKe, Knowledge and the Flow of Information, The MIT Press, Cambridge 1981; Yehoshua BAR-Hillel and Rudolf CARnAP, „Semantic Information”, British Journal for the Philosophy of Science 1953, vol. 14, no. 4, s. 147-157.
} 
Alternatywna próba klasyfikacji koncepcji informacji zaproponowana przez Nawrockiego wyróżnia (1) podejście strukturalistyczne, (2) podejście interakcyjne oraz (3) podejście „komunikatywistyczne”. Pierwsze z nich zakłada, że każdy byt materialno-energetyczny posiada niezależną od zewnętrznego obserwatora informację o sobie. Informacja ta - jako trzeci, obok materii i energii, składnik każdego bytu — jest „zakodowana” jako konstytutywny i dynamiczny ład mikro- i makrostanów wraz z regułami oddziaływań, transformacji i koherencji. Jej miarą jest negentropia. ${ }^{29}$

W ujęciu interakcyjnym, podłożem informacji są oddziaływania i ruch (zróżnicowanie), nadające bytom dynamiczne uformowanie. Oddziaływanie to ma charakter bezpośredni lub pośredni (za pośrednictwem sygnałów lub wspólnych środowisk). Układ sygnał-odbiór stanowi całość, a wzajemne „dostrajanie” się zmian oddziałujących bytów może prowadzić do powstawania hierarchicznie złożonych układów oddziałujących.

W podejściu „komunikatywistycznym” informacja nie istnieje poza sygnałami i przetwarzającymi ją odbiorcami. Jej podstawową strukturę tworzą zatem: sygnał, treść i znaczenie. Informacja polega na odwzorowaniu odebranego sygnału zmiany (inności, rożnicy) przez układ recepcyjno-przetwarzający odbiorcy na posiadane przezeń zasoby informacyjno-znaczeniowe. Szczególnego rodzaju odbiorcą jest odbiorca świadomy, to jest człowiek. Na podstawie dyspozycji właściwych jego naturze, informacja umożliwia mu nie tylko autokorektę zachowania i działania, lecz także generowanie nowych i abstrakcyjnych treści.

Złożoność filozoficznej debaty na temat definicji informacji otworzyła drogę do propozycji pluralistycznej teorii informacji, na wzór próby definicji energii w fizyce (definicja ta odwołuje się do kategorii energii potencjalnej, kinetycznej, elektrycznej, chemicznej i nuklearnej). Zwolennicy takiego podejścia wychodzą z założenia, że prawdopodobnie nie uda się wypracować jednolitej i uniwersalnej teorii informacji. Nadzieją może być według nich powstanie grupy niesprzecznych definicji, z których każda dotyczyłaby określonej sfery rzeczywistości. Ujęte w tej samej strukturze pojęciowej i operujące tym samym bądź zbliżonym językiem, mogłyby służyć jako narzędzie kompleksowego rozumienia fenomenu informacji i jej przekazywania. ${ }^{30}$

\section{Informacja biologiczna}

Zarówno informacja ilościowa jak i kategorie informacji jakościowej, strukturalnej, interakcyjnej oraz definiowanej w ujęciu relacyjnym, stanowią adekwatne wprowadze-

\footnotetext{
${ }^{29}$ Por. Nawrocki, ,W poszukiwaniu istoty informacji...”, s. 50-55.

${ }^{30}$ Por. Nawrocki, ,W poszukiwaniu istoty informacji...”, s. 41.
} 
nie do zagadnienia teorii informacji biologicznej — także w kontekście zakwestionowania genocentryzmu. ${ }^{31}$ Odniesienie do terminologii związanej z informacją $\mathrm{w}$ analizie roli genów w wyjaśnianiu rozwoju osobniczego organizmów, jak również mechanizmów międzypokoleniowego dziedziczenia cech, początkowo koncentrowało się zasadniczo na ilościowym aspekcie informacji w ujęciu Shannona. W pierwszej połowie dwudziestego wieku, w dobie projektu redukcji biologii do biochemii, chemii i fizyki, przyczynowe i korelacyjne ujęcie informacji wydawało się być jak najbardziej właściwe i wyczerpujące, nawet jeśli jego ceną było nie tyle wyjaśniające, ile inferencyjne podejście do tego, czym jest informacja biologiczna. W efekcie, nawet jeśli zasadnym było stwierdzenie, że geny zawierają nie tylko informację o białkach, lecz także o całym fenotypie organizmu, teza ta nie wykraczała poza analogicznie ujętą obserwację dotyczącą informacyjnego związku między dymem i źródłem ognia czy też liczbą słojów na pniu ściętego drzewa i jego wiekiem. ${ }^{32}$

Świadomość tego, że geny odgrywają w rozwoju organizmu rolę instruującą (to jest preskryptywną, a nie tylko deskryptywną), poniekąd „mówiąc” embrionowi, w jaki sposób ma się rozwijać, stała się źródłem sugestii, że biologia wymaga bogatszej koncepcji informacji - takiej, która będzie obejmowała także aspekty semantyczny i teleologiczny. Innymi słowy, uznano, że konieczne jest takie ujęcie informacji biologicznej, które będzie pomocne w przekroczeniu poziomu czystej korelacji i wyjaśnieniu tego, jak systemy biologiczne robią to, co robią (jak działa komórka, jaka jest droga rozwoju zygoty w dorosły organizm, w jaki sposób mechanizmy dziedziczenia genetycznego umożliwiają ewolucję bardzo złożonych fenotypów). Ważne było także wyjaśnienie możliwości występowania błędów w przekazie informacji biologicznej, co wykracza poza czysto ilościowe ujęcie Shannona.

Odpowiedzią na to wyzwanie stała się „teleosemantyczna” bądź też „teleofunkcjo-

\footnotetext{
${ }^{31}$ Budując proponowaną tu paralelę pomiędzy strategią zwracającą uwagę na konieczność kontekstualizacji DNA oraz biorącą pod uwagę narzędzia epigenetyki, biologii systemów, systemowej teorii rozwoju i evo-devo — z jednej strony — oraz strategią opierającą się na analizie pojęcia informacji biologicznej — z drugiej — warto pamiętać, że przynajmniej niektórzy zwolennicy pierwszego podejścia są sceptyczni wobec zasadności tego drugiego. I tak na przykład, twórcy systemowej teorii rozwoju twierdzą, że aplikacja terminologii związanej z pojęciem informacji w biologii prowadzi do ignorowania roli procesów kauzalnych angażujących biomolekuły. Zwracają również uwagę na niebezpieczeństwo myślenia preformacjonistycznego, to jest redukującego rozwój do wzrostu. Taki wydźwięk może mieć na przykład stwierdzenie, że budowa i kształt danego organu sa w pełni i uprzednio zdeterminowane przez informację zapisaną w genach (por. Susan Oyama, The Ontogeny of Information, Duke University Press, Durham 1985; Paul E. Griffiths and Russell D. Gray, „Developmental Systems and Evolutionary Explanation”, Journal of Philosophy 1994, vol. 91, no. 6, s. 277-304; Paul E. Griffiths and Eva M. Neumann-Held, „The Many Faces of the Gene”, BioScience 1999, vol. 49, no. 8, s. 656-662; SiedLIŃski, „Genocentryzm...”, s. 87-88).

${ }^{32}$ Por. Godfrey-Smith and Sterelny, „Biological Information...”, section 2; Siedliński, „Genocentryzm...", s. 72-73.
} 
nalistyczna" koncepcja informacji biologicznej, zakładająca, że fakt, iż dany byt (orga nizm) lub jego aspekt powstał w wyniku historycznych procesów, na które miał wpływ dobór naturalny, pozwala nam podać intencjonalny i normatywny opis jego dyspozycji przyczynowych. Klasycznym przykładem jest serce, którego funkcją jest pompowanie krwi (przyczyna wykształcenia i pozytywnej selekcji tego organu), nie zaś wydawanie dźwięków związanych z jego pracą. ${ }^{33}$ Wśród twórców i zwolenników tej koncepcji informacji biologicznej znajdują się K. Sterelny, J. Maclaurin, John Maynard Smith, E. Jablonka i N. Shea. ${ }^{34}$

Kolejnym krokiem, w perspektywie rosnącej świadomości konieczności kontekstualizacji DNA i genów, była analiza informacji biologicznej w odniesieniu do całej maszynerii komórkowej uczestniczącej w jej ekspresji. Podejście to pozwala wyjaśnić możliwość transmisji wysoce losowych i w relatywnie niskim stopniu ograniczonych sekwencji DNA oraz kompaktowość i stabilność formy przechowywania DNA w komórce oraz dokładność przekazywania zapisanej w nim informacji. ${ }^{35}$ Przejście na poziom analizy całego organizmu w powiązaniu $\mathrm{z}$ jego otoczeniem otwiera drogę do odkrycia strukturalnego, interakcyjnego oraz relacyjnego aspektu informacji biologicznej. Fakt ten poddaje jednocześnie w wątpliwość zasadność genocentryzmu. Jak zauważają Godfrey-Smith i Sterelny:

Istnieje tylko jeden rodzaj informacyjnej lub semantycznej właściwości, którą posiadają geny i tylko geny: kodowanie sekwencji aminokwasowych cząsteczek białka. Jednak ta relacja „sięga” tylko do sekwencji aminokwasowej [nie dotyczy II, III i IV-to rzędowej struktury białek]. Nie potwierdza to poglądu, że geny kodują fenotypy całego organizmu, nie mówiąc już o dostarczaniu podstawy do kompleksowego użycia języka informacyjnego lub semantycznego w biologii. ${ }^{36}$

Użycie języka zwracającego uwagę na wielorakie aspekty informacji biologicznej jest możliwe jedynie w perspektywie holistycznego spojrzenia na systemy ożywione. Wskazuje to, raz jeszcze, na konieczność krytycznej oceny genocentryzmu. ${ }^{37}$ Donio-

\footnotetext{
${ }^{33}$ Larry Wright, „Functions”, The Philosophical Review, 1973, vol. 82, s. 139-168.

${ }^{34}$ Por. Godfrey-Smith and Sterelny, „Biological Information...”, section 3; Siedliński, „Genocentryzm...", s. 73-79.

${ }^{35}$ Por. Peter Godfrey-Smith, „Genes and Codes: Lessons from the Philosophy of Mind?” w: Valerie Hardcastle (ed.), Where Biology Meets Psychology: Philosophical Essays, MIT Press, Cambridge 1999, s. 305-331; Carl T. Bergstrom and Martin Rosvall, „The Transmission Sense of Information”, Biology and Philosophy 2011, vol. 26, no. 2, s. 159-176.

${ }^{36}$ Godfrey-Smith and Sterelny, „Biological Information...”, section 4.

${ }^{37}$ Por. Piotr Lenartowicz, „Sens i zakres pojecia informacji genetycznej”, w: Koszteyn (red.), Vivere et Intelligere..., s. 133-144; Bernd-Olaf KüPPERS, Geneza informacji biologicznej. Filozoficzne problemy powstania życia, przeł. Włodzimierz Ługowski, PWN, Warszawa 1991.
} 
słość opisanej tu zmiany w paradygmacie opisu istoty bytów ożywionych staje się jeszcze bardziej widoczna w kontekście szerszego ujęcia historii rozumienia i definiowania informacji.

\section{Kilka istotnych faktów $\mathrm{z}$ historii filozofii informacji}

\section{Podejście klasyczne}

Jak już wspomnieliśmy, początki filozoficznej refleksji nad znaczeniem informacji sięgają starożytności. Tym, co cechuje klasyczne podejście do tego zagadnienia, jest szerokość spojrzenia. Pojawiające się $\mathrm{w}$ greckich tekstach terminy takie jak: عĩoos

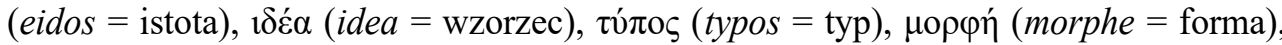
czy $\pi \rho o ́ \lambda \eta \psi 1 \varsigma$ (prolepsis = reprezentacja), wskazują na to, że informacja była postrzegana przynajmniej $\mathrm{w}$ trzech aspektach: (1) epistemologicznym (przyjmowanie przez bierny umysł wyabstrahowanych od materii form zmysłowych rzeczy będących przedmiotem ludzkiego poznania), (2) matematycznym (przyjmowanie, że forma bytu jest strukturą bądź wzorem, który można opisać za pomocą liczby) oraz (3) ontologicznym (rozumienie formy jako przyczyny, w powiązaniu z naturalną celowością właściwą każdemu bytowi).

Co więcej, klasyczne ujęcie zwraca również uwagę na statyczny i dynamiczny wymiar informacji. Widać to dobrze w źródłosłowie terminu ,informacja”. Punktem odniesienia są tu zarówno rzeczownik informatio, jak i czasownik informare. Jak zauważa Jerzy Mikułowski-Pomorski, rzeczowe informatio oznacza „wizerunek, zarys, pojęcie”, podczas gdy czynnościowe informare to tyle co „kształtować, tworzyć, wyobrażać sobie, przedstawiać, opisywać, kreślić, lecz także kształcić, uczyć”. Innymi słowy, „Informacja jest efektem informo, a sama jest formą, bo zarówno wizerunek, zarys, jak i pojęcie wymagają wyraźnego ukształtowania, odróżnienia od otoczenia. Przyjęcia postaci. Powiemy więc, że informacja to coś o określonym kształcie”. A zatem, „,hociaż informatio to «informacja», nie możemy bagatelizować aspektu procesualnego, zawartego w informo". ${ }^{38}$

W nawiązaniu do Adriaans ${ }^{39}$ możemy zaryzykować stwierdzenie, że świadomość epistemologicznych oraz ontologicznych, a także statycznych i dynamicznych aspektów pojęcia informacji zaowocowała — już w starożytności — złożonym spojrzeniem, w ramach którego możemy wyróżnić:

\footnotetext{
${ }^{38}$ Jerzy MıкUŁowsкI-PомоRsкI, Informacja i komunikacja: pojęcia, wzajemne relacje, Zakład Narodowy im. Ossolińskich, Wrocław 1988, s. 17.

${ }^{39}$ Por. AdriaAns, „Information...”, Section 2.4.
} 
1. Informację rozumianą jako proces bycia formowanym - Adriaans twierdzi, że ujęcie to sięga wstecz do Cycerona i Augustyna (porzucone w erze nowożytnej, wraca we współczesnym dyskursie nad znaczeniem terminów, takich jak computing, flowing or sending a message);

2. Informację rozumianą jako stan podmiotu - to jest rezultat procesu bycia formowanym;

3. Informację rozumianą jako dyspozycję do formowania — to jest zdolność bytu do bycia przyczyną sprawczą procesu formowania.

\section{Podejście nowożytne}

Filozoficzne reperkusje rewolucji naukowej znajdują wyraz także w filozofii informacji. Kluczowymi punktami odniesienia są tu: (1) zaproponowana już przez Galileusza ${ }^{40}$ koncepcja redukcji jakościowych do ilościowych aspektów materii oraz (2) radykalna krytyka kartezjańskiego racjonalizmu (zakładającego, że idee są wrodzone i mają charakter a priori, a formy bytów same w sobie są a-czasowe i poza-przestrzenne, to jest metafizyczne) przez empiryzm (zakładający, że idee są wytworem umysłu i mają charakter a posteriori - na podstawie wrażeń zmysłowych, formy są rozciągłe i przestrzenne, a informacja mierzalna)

Ważna dla filozofii informacji była z pewnością filozofia Locke’a, który twierdził, że każda idea jest swego rodzaju „strukturalnym symbolem zastępczym” (structural placeholder) danego bytu obecnym w umyśle. Stwierdzenie to było kolejnym krokiem na drodze do „materializacji” informacji. Co więcej, teza Locke'a, że umysł nie jest w stanie formować apodyktycznych prawd a priori odnośnie do relacji przyczynowych $\mathrm{i}$ istoty rzeczy, prowadząca w konsekwencji do stwierdzenia, że ludzka wiedza jest probabilistyczna, znalazła podatny grunt $\mathrm{w}$ postaci formalnej teorii prawdopodobieństwa, którą rozwinęli w tym czasie Blaise Pascal, Pierre de Fermat i Christiaan Huygens. ${ }^{41}$ Choć to David Hume będzie tym, który jako pierwszy formalnie powiąże formalne prawdopodobieństwo zdarzeń z epistemologią i pojęciem informacji. ${ }^{42}$

\footnotetext{
${ }^{40}$ Galileo Galilei, Il Saggiatore, Rome; The Assayer, trans. Stillman Drake and C.D. O’Malley, w: The Controversy on the Comets of 1618, University of Pennsylvania Press, Philadelphia 1960, s. 151336.

${ }^{41}$ Por. John Locke, Rozważania dotyczące rozumu ludzkiego, przeł. Bolesław J. Gawecki, Biblioteka Klasyków Filozofii, Państwowe Wydawnictwo Naukowe, Warszawa 1955, I, 4, 25.

${ }^{42}$ Por. David Hume, Badania dotyczące rozumu ludzkiego, przeł. Dawid Misztal i Tomasz Sieczkowski, Wielkie dzieła filozoficzne, Zielona Sowa, Warszawa 2005.
} 


\section{Podejście wspólczesne}

Nowożytne zmiany w rozumieniu informacji otworzyły drogę do współczesnej analizy tego pojęcia. Najważniejsze głosy w aktualnej debacie zostały przedstawione powyżej w sekcji „Współczesna analiza informacji”. Punktem wyjścia były tu prace Fishera i Shannona. Ten drugi wskazał na to, w jaki sposób pojęcie informacji może być pomocne w ilościowej analizie faktów dotyczących kontyngencji i korelacji. Ilościowe ujęcie informacji okazało się, rzecz jasna, niezwykle przydatne w rozwoju większości współczesnych technologii informacyjnych, od telegrafu po komputery. Jest to, w pewnym sensie, pozytywny owoc redukcjonizmu kauzalnego oraz redukcjonizmu w zakresie prób definicji istoty tego, czym jest informacja.

Jednocześnie, możemy z całą pewnością powiedzieć, że na gruncie nauk biologicznych podejście czysto redukcjonistyczne ustepuje dziś miejsca koncepcjom holistycznym. Przy czym te ostatnie nie wykluczają roli i użyteczności narzędzi wypracowanych w ramach dynamicznie rozwijających się szczegółowych działów biologii, takich jak biologia molekularna, biologia komórki, biochemia czy genetyka. Przeciwnie, wprzęgają je w nowe strategie modelowania systemów ożywionych, odwołując się przy tym do nowych kategorii metafizycznych właściwych dla tzw. nieredukcjonistycznego fizykalizmu, takich jak: (1) nowy mechanicyzm, ${ }^{43}$ (2) „wieloraka realizowalność” (multiple realizability) lub „kompozycyjna plastyczność” (compositional plasticity) fenomenów wyższego rzędu - w tym także fenomenu życia, ${ }^{44}$ (3) rozróżnienie pomiędzy zaktualizowanymi i ukrytymi (utajonymi — latent) własnościami materii, ujawniającymi się na wyższych poziomach jej organizacji, ${ }^{45}$ (4) superweniencja ${ }^{46}$ czy też (5) chyba najbardziej popularny dziś emergentyzm wraz z pojęciem przyczynowości odgórnej. ${ }^{47}$

${ }^{43}$ Por. Peter Machamer, Lindley Darden, and Carl F. Craver, ,Thinking about Mechanisms”, Philosophy of Science 2013, vol. 67, s. 1-25; Carl F. Craver and Lindley Darden, In Search of Mechanisms: Discoveries across the Life Sciences, University of Chicago Press, Chicago 2013; Carl CRAVER and James TABERY, „Mechanisms in Science”, w: Edward N. ZALTA (ed.) The Stanford Encyclopedia of Philosophy (Spring 2017 Edition), https://plato.stanford.edu/archives/spr2017/entries/science-mechanisms/ [08.10. 2020].

${ }^{44}$ Por. Hilary Putnam, Mind, Language and Reality: Philosophical Papers, Cambridge University Press, Cambridge 1975, s. 433-435.

${ }^{45}$ Por. Sydney Shoemaker, „Kim on Emergence”, Philosophical Studies 2002, vol. 108, s. 54 [53-63].

${ }^{46}$ Por. Jaegwon KIM, „Supervenience as a Philosophical Concept”, Metaphilosophy 1990, vol. 21, no. $1-2$, s. $1-27$.

${ }^{47}$ Por. Mariusz Tabaczen, Emergence: Towards A New Metaphysics and Philosophy of Science, University of Notre Dame Press, Notre Dame 2019. 
W kontekście, jaki tworzy zagadnienie informacji biologicznej, czysto ilościowe ujęcie Shannona - jak najbardziej adekwatne i przydatne także do analiz materiału biologicznego - jest dziś uzupełniane przez koncepcję informacji „teleosemantycznej” („funkcjonalistycznej”), w ramach rozróżnienia między podejściami strukturalistycznym, interakcyjnym oraz relacyjnym (,komunikatywistycznym”) do informacji w jej ujęciu filozoficznym. Wszystko to otwiera drogę do refleksji nad zagadnieniem informacji biologicznej także w aspektach epistemicznym i ontycznym. Wydaje się, że klasyczna propozycja Arystotelesa w tym kontekście zasługuje na szczególną uwagę. Poświęcimy jej pozostałą część niniejszego artykułu.

\section{Powrót do Arystotelesa}

W ramach systemu filozofii Arystotelesa aspekty ilościowy i jakościowy informacji biologicznej, informacja rozumiana jako bycie formowanym, stan podmiotu oraz dyspozycja do formowania, są z pewnością zakorzenione w ontologii bytu ożywionego. To w tej ostatniej należy szukać odpowiedzi na intrygujące i niełatwe pytanie o źródło informacji. Jak wiadomo, u podstaw swojej ontologii Arystoteles stawia tezę, że przyczyna stałości i zmian bytów w naturze ma więcej aspektów niż tylko ten fizyczny (możliwy do pomiaru empirycznego i przedstawienia za pomocą języka matematyki). Przyczyna dla Arystotelesa to droga racjonalnego wyjaśnienia rzeczywistości, która wykracza poza to, co fizykalne - jest zasadą metafizyczną.

\section{Hylemorfizm}

Jako pierwszy biolog, obserwując zachowanie i badając anatomię organizmów żywych, Arystoteles stwierdza, że obok wszystkich fizykalnych zależności pomiędzy częściami składowymi systemów ożywionych (które można analizować na tle przyczynowości sprawczej), dla zrozumienia ich istoty trzeba uznać, że mają one także przyczynę formalną - metafizyczną zasadę sprawiającą, że są tym, czym są. Spośród terminów, które Arystoteles używa na określenie tego rodzaju przyczynowości w swoich słynnych zestawieniach przyczyn w Fizyce i Metafizyce oraz w innych dziełach, najbardziej adekwatne wydaje się być enigmatycznie brzmiące i sprawiające trudności w przekła-

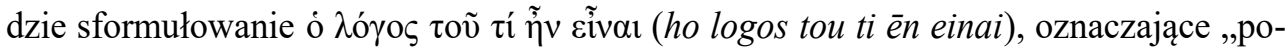
jęcie istoty” bytu, oraz greckie $\pi \alpha \rho \alpha ́ \delta \varepsilon \gamma \gamma \mu \alpha$ (paradeigma), tłumaczone jako „archetyp”, „model”, „wzór”, czy „,charakterystyka danego typu”. ${ }^{48}$

\footnotetext{
${ }^{48}$ Arystoteles używa jeszcze dwóch innych terminów na określenie przyczyny formalnej. Pierwszym z nich jest dość często pojawiający się w jego pismach, wspomniany powyżej, termin cĩos (eidos), który w dosłownym tłumaczeniu oznacza ,zewnętrzną, widzialną postać osoby czy przedmiotu” (choć Leopold Regner w tłumaczeniu O powstawaniu i niszczeniu oddaje ten sam termin jako ,postać istotowa”). Drugim
} 
Przyczyna formalna jest dla Arystotelesa metafizycznym gwarantem jedności i spójności niezliczonych procesów i zależności zachodzących w każdym organizmie żywym. Jest zasadą aktualizującą materię - jednak nie materię w sensie fizycznym, ale materię rozumianą metafizycznie jako materia pierwsza, czyli zasada potencjalności.

Tak rozumiana materia stanowi kolejną kategorię w zestawieniu przyczyn zaproponowanym przez Arystotelesa. W opozycji do atomizmu, który ma poważne trudności $\mathrm{w}$ thumaczeniu zmiany/przejścia jednej substancji w drugą inaczej niż tylko na drodze reorientacji niezmiennych atomów (cząstek elementarnych), co wydaje się być w efekcie jedynie zmianą przypadłościową (akcydentalną), Stagiryta stwierdza, że u podstaw każdego bytu we wszechświecie oraz wszelkich zmian, którym dany byt podlega, leży metafizyczna zasada potencjalności, którą określa mianem materii pierwszej ( $\pi \rho \omega ́ \tau \eta$

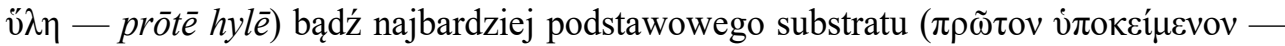
prōton hypokeimenon).

Warto zauważyć, że definiując przyczynę materialną, zarówno w Fizyce, jak i w Metafizyce, Arystoteles podaje dwa przykłady: posągu z brązu oraz srebrnego pucharu: „W jednym przeto znaczeniu nazywa się przyczyną to, z czego coś powstaje i co trwa, na przykład brąz jest $\mathrm{w}$ tym sensie przyczyną posągu, a srebro naczynia". ${ }^{49}$ „Przyczyną nazywa się, po pierwsze: (1) materia, z której coś powstaje, na przykład brąz jest przyczyną posagu, a srebro pucharu". ${ }^{50}$ Powierzchowna lektura dzieł Arystotelesa w tej kwestii może rodzić ogólne przekonanie, że definiuje on materię jako empirycznie weryfikowalny materiał budulcowy. Wydaje się, że taka właśnie interpretacja dominuje wśród współczesnych zwolenników myśli Stagiryty, wywodzących się z kręgów analitycznej tradycji metafizycznej o nastawieniu mereologicznym. Tymczasem dokładna analiza rozumienia materii w pismach Arystotelesa nie pozostawia wątpliwości, że u podstaw każdego bytu materialnego widzi on nie tyle fizyczny materiał budulcowy (brąz czy srebro i tym podobne — określane przez scholastyków mianem materii

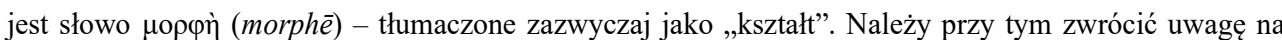

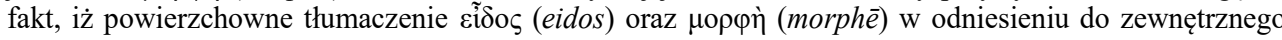
„kształtu” czy „postaci”, w jakiej byt jawi się nam w podstawowym oglądzie zmysłowym, może prowa dzić do redukcji metafizycznego znaczenia przyczyny formalnej do zewnętrznego, geometrycznego aspektu danego bytu. Taka interpretacja (nieobca wielu współczesnym zwolennikom myśli Arystotelesa w filozofii analitycznej) nie oddaje w sposób właściwy myśli Stagiryty. Por. Arystoteles, Fizyka, przeł. Kazimierz Leśniak, Dzieła wszystkie, t. 2, Wydawnictwo Naukowe PWN, Warszawa 2003, II, 3 (194b 26-28); Arystoteles, Metafizyka, przeł. Kazimierz Leśniak, Dzieła wszystkie, t. 2, Wydawnictwo Naukowe PWN, Warszawa 2003, V, 2 (1013a 27-28); Arystoteles, O powstawaniu i niszczeniu, przeł. Kazimierz Leśniak, Dzieła wszystkie, t. 2, Wydawnictwo Naukowe PWN, Warszawa 2003, II, 9 (335b 7).

${ }^{49}$ Arystoteles, Fizyka..., II, 3 [194b 24-25].

${ }^{50}$ Arystoteles, Metafizyka..., V, 2 [1013a 24-26]. 
wtórej) lecz właśnie materię pierwszą, to jest metafizyczną zasadę potencjalności. W VII księdze Metafizyki czytamy: „Ostateczny substrat nie jest sam przez się ani poszczególną rzeczą, ani określoną ilością, ani żadną inną kategorią [określającą byt]; nie jest też ich zaprzeczeniem”. ${ }^{51}$ Natomiast w Fizyce Arystoteles dodaje: „Albowiem moja definicja materii ma brzmienie następujące: materia jest to pierwotny substrat ( w sposób nieprzypadkowy". ${ }^{52}$

Materia pierwsza jako zasada potencjalności jest aktualizowana przez formę. Innymi słowy, każdy przedmiot (byt) w naturze jest według Arystotelesa - metafizycznie rzecz ujmując - złożeniem materii pierwszej i formy substancjalnej, rozumianej nie jako geometryczny kształt, ale jako zasada aktualizująca i sprawiająca, że dany byt jest tym, czym jest. Złożenie tych przyczyn jest określane mianem hylemorfizmu — od

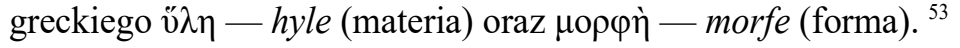

\section{Hylemorfizm w kontekście pytania o istotę życia}

W debacie na temat istoty życia, hylemorfizm daje bardzo klarowną odpowiedź na pytanie o zasadę jedności organizmu żywego (jedność wszystkich procesów w nim zachodzących). Tą zasadą jedności jest forma substancjalna, aktualizująca materię pierwszą, rozumianą jako źródło wszelkiej potencjalności w naturze. To prawda, że obserwując i badając przyrodę z pozycji nauk ścisłych, możemy wyodrębnić określone elementy składowe czy cząstki elementarne wchodzące w skład systemów złożonych. Co więcej, te same nauki szczegółowe są także w stanie śledzić ich „losy” i „zachowanie” (aktywność i reaktywność) wewnątrz organicznej całości danego bytu ożywionego. Jedno-

\footnotetext{
${ }^{51}$ Arystoteles, Metafizyka..., VII, 3 [1029a 24-25].

${ }^{52}$ Arystoteles, Fizyka..., I, 9 [192a 31-32].

${ }^{53}$ Warto zauważyć, że w kontekście antyredukcjonistycznego zwrotu w niektórych kręgach filozofii nauki, analitycznej metafizyki oraz filozofii umysłu, hylemorfizm ponownie zyskuje na popularności. Co prawda sposób jego definiowania wśród filozofów wywodzących się z tradycji analitycznej rodzi uzasadnione pytania o wierność oryginalnej myśli Arystotelesa i jego komentatorów, niemniej jednak sam fakt nawiązania filozofii analitycznej do hylemorfizmu jest znaczacy. Por. Kathrin KosLICKI, The Structure of Objects, Oxford University Press, Oxford 2010, rozdz. 6-7; Mark JoHnston, „Hylomorphism”, Journal of Philosophy 2006, vol. 103, no. 12, s. 652-698; Kit FINE, „Things and Their Parts”, Midwest Studies in Philosophy 1999, vol. 23, s. 61-74; William JAWORSKI, Structure and the Metaphysics of Mind: How Hylomorphism Solves the Mind-Body Problem, Oxford University Press, Oxford 2016; E.J. Lowe, „A NeoAristotelian Substance Ontology: Neither Relational nor Constituent", w: Tuomas E. TAнKo (ed.), Contemporary Aristotelian Metaphysics, Cambridge University Press, Cambridge 2011, s. 229-248; Gordon P. Barnes, „The Paradoxes of Hylomorphism”, The Review of Metaphysics 2003, vol. 56, s. 501-523; Anna Marmodoro „Aristotle's Hylomorphism Without Reconditioning”, Philosophical Inquiry 2013, vol 37, s. 5-22. Na temat krytycznej analizy definicji hylemorfizmu zaproponowanych w filozofii analitycznej por. TАВACZEK, Emergence..., s. 216-37.
} 
cześnie, nic nie stoi na przeszkodzie, aby stwierdzić, iż — z metafizycznego punktu widzenia — istota zjednoczenia części tworzących organiczną całość polega nie tyle na ich agregacyjnej czy dynamicznej interakcji (podlegającej empirycznej weryfikacji oraz opisowi matematycznemu), lecz na zmianie substancjalnej, w której części tracą swoją pierwotną ontologiczną tożsamość (formę substancjalną), a leżąca u ich podstaw materia pierwsza (źródło potencjalności) zostaje „uformowana” przez nową formę substancjalną organizmu. ${ }^{54}$

Innymi słowy, możliwość fizycznej lokalizacji części w całości nie wyklucza ich metafizycznej (substancjalnej) zmiany w procesie powstania organizmu żywego, bądź przy wejściu w jego skład na późniejszym etapie jego trwania w czasie i przestrzeni. Można to wykazać na przykładzie zasad azotowych będących częścią nukleotydów wchodzących w skład DNA. Z jednej strony, jesteśmy w stanie stwierdzić eksperymentalnie, że właściwa im aktywność i reaktywność jest zachowana w organizmie żywym. Z drugiej strony, odczytanie kodu DNA udowodniło, że kolejność zasad azotowych w łańcuchu DNA staje się nośnikiem informacji genetycznej, której treść przyczynia się do prawidłowego funkcjonowania całego organizmu żywego. Cechy tej nie można przypisać zasadom azotowym poza organizmem żywym (poza strukturą DNA), pomimo tego, że chemicznie rzecz ujmując, molekuły te posiadają identyczną budowę. Badane in vitro $\mathrm{w}$ żaden sposób nie mają wkładu w utrzymanie stanu równowagi jakiegokolwiek bytu ożywionego.

W tym miejscu należy raz jeszcze podkreślić, że metafizyczna teoria hylemorfizmu — kładąca nacisk na prawdziwość istnienia i rolę formy substancjalnej w aktualizowaniu materii pierwszej, rozumianej jako źródło potencjalności — stanowi bardzo konkretną odpowiedź w debacie nad zasadą jedności systemów ożywionych oraz tożsamości części, które wchodzą w ich skład. Zasady azotowe w cząsteczce DNA organizmu żywego, choć chemicznie tożsame ze swoimi odpowiednikami badanymi in vitro, z metafizycznego punktu widzenia są obecne w holistycznie ujętym systemie ożywionym na sposób virtute (poprzez moce, to jest właściwe im sposoby akcji i reakcji). Ponieważ materia pierwsza leżąca u ich podstaw jest zaktualizowana przez formę sub-

\footnotetext{
${ }^{54}$ Arystoteles zdawał sobie sprawę z tego, że elementy wchodzące w skład organicznej całości, tracąc przy tym formę substancjalną, nie ulegają jednocześnie unicestwieniu i mogą być z niej na nowo wyodrębnione (na drodze kolejnej zmiany substancjalnej). Jego stanowisko w kwestii obecności części w całości, przyjęte i komentowane przez filozofów scholastycznych, jest określane mianem „obecności wirtualnej” (virtute), przy czym chodzi tu nie tyle o obecność „nierealną” (synonim terminu „wirtualny”), co raczej o obecność „przez moce”, czyli zdolności akcji i reakcji. Jest to zatem obecność realna w stanie nie-wpełni-zaktualizowanym. W O powstawaniu i niszczeniu czytamy: „Ponieważ zaś jedne z bytów istnieją w możności, drugie zaś w urzeczywistnieniu, przeto składniki zespolenia mogą w pewnym znaczeniu istnieć, w pewnym zaś nie istnieć, skoro coś innego, co z nich powstało, istnieje w urzeczywistnieniu, każde natomiast z tych, które istniały, zanim się zespoliły, istnieje w możności i nie unicestwione" (ARYSTOTELES, O powstawaniu i niszczeniu..., I, 10 [327b 24-26]).
} 
stancjalną danego organizmu, możemy im także przypisać czynny udział w utrzymywaniu jego homeostazy oraz właściwego funkcjonowania i rozwoju. W przeciwieństwie do języka opisu i narracji typowej dla nauk szczegółowych, przypisanie tego typu cech elementom składowym całości w ujęciu hylemorficznym nie ma charakteru arbitralnego, gdyż jest ufundowane na metafizycznej zasadzie jedności organizmu. Jest nią złożenie potencjalności materii pierwszej i aktualizującej ją formy substancjalnej danego bytu.

\section{Teleologia i przypadek}

Zwrócenie uwagi na fakt współudziału zasad azotowych wchodzących w skład DNA organizmu żywego w utrzymaniu optymalnego stanu jego funkcjonowania niesie w sobie odwołanie do jeszcze jednej przyczyny w katalogu przyczyn Arystotelesa. Chodzi mianowicie o przyczynę celową — jeszcze jeden aspekt racjonalnego rozumienia i wyjaśniania rzeczywistości, nierozerwalnie związany z przyczynowością formalną (jak również materialną i sprawczą). Przyczyna ta jest definiowana jako wewnętrzne dążenie każdego bytu do realizacji swojej istoty (formy substancjalnej) w całej pełni (stąd powszechne określanie jej mianem zasady teleologicznej, od greckiego $\tau \varepsilon ́ \lambda o \varsigma$, to znaczy „koniec”). ${ }^{55}$

Ten rodzaj przyczynowości był szeroko omawiany w rozważaniach biologów w całej historii tej nauki. Odrzucany na wielu etapach tej historii, nieustannie wraca pod nową postacią. We współczesnej obronie koncepcji naturalnej celowości bytów ożywionych i nieożywionych w przyrodzie podkreśla się, że w tej koncepcji chodzi nie tyle o fizykalną przyczynę działającą z przyszłości na teraźniejszość (co byłoby źródłem poważnych wątpliwości natury ontologicznej), co raczej o naturalną metafizyczną tendencję danego bytu do realizacji i „wyrażenia” w pełni tego, czym jest w samej swojej istocie. W nawiązaniu do Arystotelesa podkreśla się, że zasada celowa może być niezwiązana z aktywnością podmiotu myślącego, przez co można ją odnosić do wszystkich bytów w przyrodzie: „Byłoby to niedorzecznością sądzić, że nie ma celowości, ponieważ nigdzie się nie widzi, by czynnik ruchu rozmyślał nad celem". ${ }^{56}$

${ }^{55}$ W O częściach zwierząt Arystoteles stwierdza: „W rzeczy samej, cokolwiek powstaje, pochodzi od jakiejś rzeczy ( $\dot{\alpha} \rho \chi \eta ́ ~-~ a r c h \bar{e})$ i zdąża do innej; rodzenie jest przejściem od jednej zasady do drugiej; od jednej formy, która pierwsza wprawia w ruch i już posiada daną naturę, do jakiejś formy lub jakiegoś innego podobnego celu ( $\tau \dot{\lambda}$ os — telos)" (Arystoteles, O częściach zwierząt, przeł. Paweł Siwek, Dzieła wszystkie, t. 3, Wydawnictwo Naukowe PWN, Warszawa 1992, II, 1 [646a 32-35]. Por. też Arystoteles, O częściach zwierząt..., III, 2 (663b 12-14); IV, 5 (679a 25-30). Głębokie przekonanie Arystotelesa, że natura nie czyni niczego na próżno każe mu stwierdzić, że wszystko w przyrodzie musi mieć swój cel.

${ }^{56}$ Arystoteles, Fizyka..., II, 8 (199b 26-27). Bardziej szczegółowe omówienie przyczyny celowej i bogatej literatury na jej temat przekracza ramy naszych rozważań. Dobrym wstępem do studium teleologii mogą być następujące pozycje: Allan Gotrhelf, Teleology, First Principles, and Scientific Method in 
Odwołując się raz jeszcze do przykładu zasad azotowych w cząsteczce DNA oraz ich udziału w prawidłowym funkcjonowaniu i rozwoju organizmu żywego, należy uznać, że twierdzenie to jest zrozumiałe i ma sens jedynie w kontekście uznania tego, że tendencja do utrzymania homeostazy w czasie i przestrzeni, jak również tendencja do rozwoju i wydania potomstwa jest naturalnym celem organizmu żywego, nierozerwalnie związanym z samą jego istotą. Bez wewnętrznej teleologii trudno wyjaśnić określone kierunki reakcji biochemicznych oraz zachowanie (aktywność i reaktywność) biomolekuł w systemie ożywionym.

Warto zauważyć, że klasycznie definiowana zasada przyczynowości celowej ma także charakter normatywny, tzn. odnosi się do dobra właściwego dla danego bytu. Mark Bedau broni owego normatywnego charakteru teleologii, wskazując na to, że jako element wartościujący, nie musi się on z konieczności odnosić do żadnego dobra moralnego, czy też dobra istotnego lub najwyższego. Wręcz przeciwnie, wystarczy odniesienie do jakiegoś dobra: „moralnego lub pozamoralnego, czy nawet niemoralnego, istotnego lub nie istotnego, wewnętrznego lub jedynie instrumentalnego". ${ }^{57}$ Dobro to pozostaje zawsze $\mathrm{w}$ relacji do tego, czym dany byt jest w swej istocie (ze względu na właściwą mu formę substancjalną). Dlatego też - nawet jeśli może być właściwie sklasyfikowane i określone nie inaczej, jak tylko na drodze świadomej analizy filozoficznej - dobro leżące u podstaw normatywnego charakteru każdego bytu jest samo w sobie niezależne od umysłu badacza przyrody.

Jednocześnie, wewnętrzna celowość bytu nie wyklucza zdarzeń o charakterze przypadkowym. Przeciwnie, determinizm procesów życiowych jest, w rozumieniu Arystotelesa, warunkowy (supozycyjny). Na drodze pełnej aktualizacji organizmu mogą stanąc inne byty, działające per se bądź przypadkowo, to jest per accidens, jednak zawsze w odniesieniu do właściwych przyczyn materialnych, formalnych, celowych i sprawczych bytów uczestniczących w takim zdarzeniu. Innymi słowy, regularność zawsze poprzedza i stanowi podłoże dla przypadku, który ma charakter ontologiczny, a nie tylko epistemiczny, to jest wynikający z naszej nieznajomości przyczyn. ${ }^{58}$

Aristotle's Biology, Oxford University Press, Oxford 2012; Monte R. Johnson, Aristotle on Teleology, Clarendon Press, Oxford 2005; Denis M. WALSH „Teleology”, w: Michael Ruse (ed.), The Oxford Handbook of Philosophy of Biology, Oxford University Press, Oxford, New York 2008, s. 113-137; Mark Perlman, „The Modern Philosophical Resurrection of Teleology”, w: Alex Rosenberg and Robert ARP (eds.), Philosophy of Biology: An Anthology, Blackwell, Oxford 2010, s. 149-163; Robert Cummins, „Neo-Teleology”, w: Rosenberg and Arp (eds.), Philosophy of Biology..., s. 164-174.

${ }^{57}$ Mark Bedau, „Where's the Good in Teleology?”, Philosophy and Phenomenological Research 1992, vol. 52, s. 791 [781-806].

${ }^{58}$ Por. Arystoteles, Fizyka..., II, 3 [195a 26-34]; II, 5 [196b 24-29]; II, 7, [198a 23-26].Wyjątkowy status przypadku w ujęciu Arystotelesa opisuje zwięzłe stwierdzenie w Fizyce..., II, 5 (197a, 12-14), w którym Stagiryta przyznaje, że „Przypadek w sensie absolutnym nie jest przyczyną niczego”. 


\section{Arystotelesowska ontologia informacji biologicznej}

W świetle nakreślonej tu ontologii Arystotelesa możemy stwierdzić, że informacja biologiczna jest zakorzeniona $w$ metafizycznych zasadach (przyczynach) formalnej i celowej, znajduje zaś wyraz w konkretnym bycie ożywionym (materia wtóra) oraz jego dyspozycjach — biernych i czynnych (przyczynowość sprawcza). A zatem, informacja biologiczna $\mathrm{w}$ aspektach ilościowym $\mathrm{i}$ jakościowym nie jest jedynie pochodną czy epifenomenem dynamicznie rozumianej materialnej struktury bytu ożywionego. Struktura ta wymaga bowiem wytłumaczenia (nie jest czymś oczywistym, ontycznie rzecz ujmując). Strukturalny aspekt informacji biologicznej jest raczej wyrazem/pochodną formy substancjalnej, aktualizującej metafizycznie zdefiniowaną materię pierwszą oraz organizującej fizykalną materię wtórą w bardziej prymitywnym bądź bardziej złożonym (organicznym) systemie ożywionym.

Arystotelesowska przyczyna celowa (teleologalna) funduje z kolei ,teleosemantyczny” bądź też „teleofunkcjonalistyczny” aspekt informacji biologicznej, który jest kluczowy dla właściwego rozumienia i ontologicznego ugruntowania nie tylko regularnego funkcjonowania organizmu żywego, lecz także systemowej teorii rozwoju (developmental system theory) oraz ewolucyjnej biologii rozwoju (evolutionary developmental biology - evo-devo). Te same przyczyny - formalna i celowa — leżą także u podstaw aspektów interakcyjnego oraz relacyjnego („komunikatywnego”) informacji biologicznej.

Wydaje się, że niematerialny (metafizyczny) charakter przyczyn formalnej i celowej, postrzeganych jako podstawa informacji biologicznej, wskazuje na podobnie niematerialny (metafizyczny) charakter tejże informacji. Zwraca na to uwagę Nawrocki, który stwierdza, że „wysoce intrygującym aspektem sygnałów generujących informację jest związek z nośnikami materialno-energetycznymi: służą one do jej przekazywania, informacja jednak może być od nich oddzielana, kopiowana na inne nośniki i tak dalej, chociaż jako taka w «wyizolowanej» postaci nie istnieje w świecie fizycznym". ${ }^{59}$ Innymi słowy, jeśli nasza intuicja jest słuszna, mielibyśmy tu do czynienia z paradoksem bytu metafizycznego, którego niematerialny charakter pozwala na wędrówkę między różnymi nośnikami i który nie może jednocześnie istnieć w oderwaniu od materii (w rozumieniu materii wtórej, to jest konkretnego bytu fizycznego). Widać tu wyraźną analogię do formy substancjalnej, która także istnieje jedynie jako aktualizująca materię pierwszą, nie zaś jako oddzielny byt (poza wyjątkiem duszy ludzkiej subzystującej po śmierci człowieka). Przy czym w przypadku form substancjalnych nie możemy mó-

\footnotetext{
${ }^{59}$ NAwrocki, „W poszukiwaniu istoty informacji...”, s. 61.
} 
wić o ich przekazywaniu czy wędrówce (formy substancjalne są wyprowadzane z potencjalności materii — więcej na ten temat poniżej).

\section{Aktualność stanowiska Arystotelesa}

Nasz argument na rzecz powrotu do klasycznej filozofii Arystotelesa nie jest odosobniony. W ostatnich latach możemy obserwować renesans jego myśli, w tym także $\mathrm{w}$ dziedzinie metafizyki oraz filozofii przyrody i nauki. ${ }^{60} \mathrm{~W}$ kontekście polskiego środowiska filozoficznego, na tle wieloaspektowej analizy problemów dotyczących filozofii przyrody ożywionej, ${ }^{61}$ wielkim orędownikiem powrotu do biologii i ontologii bytów ożywionych Arystotelesa był Piotr Lenartowicz. Jego poglądy w tej kwestii bardzo dobrze obrazują publikacje zebrane w jubileuszowym tomie pod redakcją Jolanty Koszteyn. ${ }^{62}$ Zgadzając się z kluczowymi tezami argumentacji Lenartowicza, należy zwrócić uwagę na kilka zasadniczych różnic w naszym podejściu do dziedzictwa Stagiryty.

\section{Reinterpretacja rozumienia materii i formy}

Lenartowicz wspomina kilkukrotnie o konieczności „zmodyfikowania arystotelesowskiej koncepcji życia biologicznego". ${ }^{63}$ Pierwszym przedmiotem wymagającym korekty jest, według niego, pojęcie materii. Lenartowicz wydaje się odrzucać pojęcie materii pierwszej jako „bardzo wysublimowane, wyabstrahowane i wyidealizowane”. ${ }^{64}$

${ }^{60}$ Por. TАнко (ed.), Contemporary Aristotelian Metaphysics...; Daniel D. NovotnÝ and Lukáš Novák (eds.), Neo-Aristotelian Perspectives in Metaphysics, Routledge, New York 2014; William M.R. Simpson, Robert C. Koons, and Nicholas J. Tен (eds.), Neo-Aristotelian Perspectives on Contemporary Science, Routledge, New York 2018, zwłaszcza artykuły w drugiej części tego zbioru; oraz William M.R. Simpson, Robert C. Koons, and James OrR (eds.), Neo-Aristotelian Metaphysics and the Theology of Nature, Routledge, New York 2021.

${ }^{61}$ Por. Stanisław MAZIERSKi (red.), Zarys filozofii przyrody ożywionej, KUL, Lublin 1980; Michał Heller, Mieczysław LubaŃSKi i Szczepan W. ŚLAGA, Zagadnienia filozoficzne wspólczesnej nauki, wyd. 4, Akademia Teologii Katolickiej, Warszawa 1997; Tadeusz WoлcIeсноwsкi, Zarys filozofii przyrody ożywionej, Wydział Teologiczny Uniwersytetu Opolskiego, Opole 1997; Michał TемРсzYк, Ontologia świata przyrody, Universitas, Kraków 2005; Chodasewicz, Grabizna, Proszewska, Stencel i Ziemny (red.), Glówne problemy filozofii biologii...; Anna LATAWIEC i in. (red.), Filozoficzne i naukowo-przyrodnicze elementy obrazu Świata, vol. 1-8, Wydawnictwo ATK, Warszawa 1996-2010.

${ }^{62}$ Por. Koszteyn (red.), Vivere et Intelligere.... Por. zwłaszcza następujace artykuły Lenartowicza: „Trzy koncepcje dynamiki biologicznej: Arystotelesowska, neo-darwinowska, inteligentnego projektu”, w: Koszteyn (red.), Vivere et Intelligere..., s. 285-303; „Wyjściowe przesłanki teorii życia biologicznego”, w: Koszteyn (red.), Vivere et Intelligere..., s. 305-315; „Czy istnieją «dusze» roślin i zwierząt, a jeśli tak, to skąd się one biorą?”, w: KoszTeyn (red.), Vivere et Intelligere..., s. 317-336; „Struktura bytu żywego w arystotelizmie", w: Koszteyn (red.), Vivere et Intelligere..., s. 355-379.

${ }^{63}$ Lenartowicz, „Trzy koncepcje dynamiki biologicznej...”, s. 288 [wyróżnienia w oryginale].

${ }^{64}$ Lenartowicz, „Czy istnieją «dusze» roślin i zwierząt...”, s. 326. 
$\mathrm{Na}$ innym miejscu, w podobnym duchu stwierdza, że „materia pierwsza, jako absolutnie czysta możność bierna, jest pojęciem granicznym, wyidealizowanym, skrajnie wyabstrahowanym". ${ }^{65}$ Według niego ,forma żywa wykorzystuje [organizuje] materie mineralna", ${ }^{66}$ przy czym nie dzieje się to, jak twierdził Arystoteles, na drodze zmiany substancjalnej. Przeciwnie, ,należałoby raczej mówić o przejęciu kontroli nad materiałem zasymilowanym, a nie o jego całkowitej, sięgającej substancji zmianie. Dynamika zasymilowanych cząsteczek materii mineralnej nie jest w ciele żywym zmieniona, a jedynie bardzo ograniczona". ${ }^{67}$

Takie ujęcie hipostazuje formę substancjalną (duszę wegetatywną), sugerując, że jako zasada metafizyczna, dokonuje określonych działań na bytach fizycznych. Lenartowicz zdaje się twierdzić, że jest to stanowisko samego Arystotelesa: „Działanie duszy (rozumianej jako forma substancjalna) bez postugiwania się narzędziami materialnymi wydaje się, w ramach teorii arystotelesowskiej, niemożliwe. ${ }^{68}$ Tymczasem w ujęciu Stagiryty korelatem metafizycznej kategorii formy substancjalnej wydaje się być, także metafizyczna, kategoria materii pierwszej. Co więcej, Lenartowicz hipostazuje nie tylko formę substancjalną, lecz także materię pierwszą, definiując ją jako „materiał pozbawiony jakichkolwiek konkretnych cech i właściwości (ne quid, ne quale, ne quantum)". ${ }^{69}$ Dodaje przy tym, że „W świetle nowoczesnej wiedzy chemicznej i biochemicznej takie stanowisko wydaje się dosyć dziwne i niewiarygodne. Formy życiowe mogą asymilować tylko pewne szczególne postacie materiału i energii mineralnej”. ${ }^{70}$ W innym miejscu dodaje: „Gdyby rzeczywiście element materialny żywego ciała należało rozumieć jako materię pierwszą, wtedy rodzaj pokarmu lub energii wykorzystywanej przez daną formę życiową nie miałby chyba znaczenia". ${ }^{71}$

Wydaje się, że Lenartowicz nie odróżnia zmiany akcydentalnej od substancjalnej. Oczywistym jest fakt, że organizm przyswaja określonego typu materię wtórą, nie zaś materię pierwszą, która nie istnieje samodzielnie (nie jest konkretnym materiałem, lecz zasadą metafizyczną). Jednak proces przyswajania w ujęciu Arystotelesa jest zmianą substancjalną, w której zostaje zaktualizowana nowa potencjalność leżącej u podstaw

\footnotetext{
${ }^{65}$ Piotr Lenartowicz i Jolanta Koszteyn, Wprowadzenie do zagadnień filozoficznych, WAM, Kraków 2000, s. 169 [wyróżnienia w oryginale].

${ }^{66}$ Lenartowicz, „Trzy koncepcje dynamiki biologicznej...”, s. 288 [wyróżnienia w oryginale].

${ }^{67}$ Lenartowicz, „Trzy koncepcje dynamiki biologicznej...”, s. 288.

${ }^{68}$ Lenartowicz, „Trzy koncepcje dynamiki biologicznej...”, s. 291 [wyróżnienia w oryginale].

${ }^{69}$ Lenartowicz, „Trzy koncepcje dynamiki biologicznej...”, s. 288.

${ }^{70}$ Lenartowicz, „Trzy koncepcje dynamiki biologicznej...”, s. 289 [wyróżnienia w oryginale].

${ }^{71}$ Lenartowicz, „Czy istnieją «dusze» roślin i zwierząt...”, s. 333.
} 
danego bytu materii pierwszej. W ujęciu Lenartowicza mamy tu do czynienia jedynie ze zmianą akcydentalną. Stanowisko to (atomistyczne u swoich podstaw) natrafia na trudność, którą Lenartowicz zauważa pytając: „Czy zatem organizm żywy jest wielosubstancjalny?” Na co odpowiada: „Arystotelizm traktuje byt żywy (konkretną jego formę — psią, kocią, bakteryjną czy dębową) jako całość. Jest to całość złożona". ${ }^{72}$ Taka odpowiedź jest wymijająca. W świetle zacytowanych fragmentów nie ulega wątpliwości, że stanowisko Lenartowicza odchodzi od hylemorfizmu w stronę meromorfizmu. ${ }^{73}$ Wydaje się, że jest to konsekwencją próby weryfikacji i uwiarygodnienia stanowiska metafizycznego na gruncie analizy empirycznej.

Oczywiście próba reinterpretacji hylemorfizmu oraz koncepcji „obecności wirtualnej” (virtute), rozumianej jako obecność ,przez moce”, czyli zdolności akcji i reakcji (obecność realna w stanie nie-w-pełni-zaktualizowanym) jest jednym $\mathrm{z}$ największych wyzwań dla nowego arystotelizmu. W sekcji poświęconej hylemorfizmowi, w kontekście pytania o istotę życia podjęliśmy próbę takiej reinterpretacji tej koncepcji, która pozostaje wierna oryginalnemu stanowisku Arystotelesa. Propozycja Lenartowicza jest zasadniczo różna i znacząco odbiega od ortodoksyjnej lektury Stagiryty.

\section{Skąd się biorą formy substancjalne?}

Innym zagadnieniem, które stanowi trudne wyzwanie dla nowego arystotelizmu i tomizmu jest pochodzenie form substancjalnych. Klasyczna myśl Tomasza z Akwinu mówi o „wydobywaniu” form substancjalnych (dusz wegetatywnych i zmysłowych dusze rozumne są według niego stwarzane ex nihilo w momencie poczęcia się człowieka) z potencjalności materii: „Wszak poruszanie znaczy: dobyć coś z możności istnienia do rzeczywistości [educere aliquid de potentia in actum]". ${ }^{74}$ Jeśli zatem możemy powiedzieć, że forma «przed-istnieje» w materii, jest w niej obecna jako niezaktualizowana: „Wszelkie urzeczywistnienie jakiejś materii, jak się zdaje, jest dobywane z możności materii [educi de potentia materiae]. Skoro bowiem materia jest w możności do urzeczywistnienia, wszelkie urzeczywistnienie istnieje uprzednio $\mathrm{w}$ materii $\mathrm{w}$ postaci możności”. ${ }^{75}$ „Każda forma, która zaczyna istnieć przez przemianę materii, jest formą wyprowadzoną z możności materii [forma educta de potentia materiae]". ${ }^{76} \mathrm{~W}$ konse-

\footnotetext{
${ }^{72}$ Lenartowicz, „Trzy koncepcje dynamiki biologicznej...”, s. 289 [wyróżnienia w oryginale].

${ }^{73}$ Por. Tadeusz WoJciechоwsкi, Teoria hylemorfizmu w ujęciu autorów neoscholastycznych, ATK, Warszawa 1967.

${ }^{74}$ Tomasz z Aкwinu, Summa theologiae, I, 2, 3, co., https://tiny.pl/9118g [08.10.2020].

${ }^{75}$ Tomasz z Akwinu, Summa theologiae.... I, 90, 2, ob. 2 , ad 2.

${ }^{76}$ Tomasz z Akwinu, Summa contra gentiles, II, 86, https://tiny.pl/9118g [08.10.2020]. Por. też To-
} 
kwencji, możemy powiedzieć, że przyczyna sprawcza wytwarza (inducere) lub wprowadza (introducere) formę substancjalną.

Precyzyjne wyjaśnienie i obrona stanowiska Akwinaty odnośnie do źródła form substancjalnych nie jest łatwe. Wydaje się, że fenomen „wyprowadzania” form przez przyczyny sprawcze można rozumieć jako działanie tychże przyczyn sprawiające, że dana porcja materii zaczyna istnieć „na sposób” właściwy dla określonego rodzaju naturalnego. Oczywiście, przedmiotem działania przyczyn sprawczych jest materia wtóra. Jeśli jednak ich działanie prowadzi do radykalnej zmiany, będącej zmianą substancjalną, nowego rodzaju aktualizacji podlega materia pierwsza (będąca u podstaw materii wtórej, która jest przedmiotem danego działania). Mamy tu zatem do czynienia $\mathrm{z}$ dwoma poziomami potencjalności - potencjalnością materii wtórej (ograniczoną, relatywną) oraz potencjalnością materii pierwszej (nieograniczoną, czystą). Ich aktualizacja nie jest samoczynna. Wymaga działania przyczyn sprawczych, które są zaktualizowanymi bytami, posiadającymi konkretne czynne i bierne dyspozycje. Przyczyny te mogą działać w pojedynkę lub być częścią złożonego zbioru przyczyn. Nie muszą przy tym być bytami aktualizowanymi tego samego rodzaju formą substancjalną, co forma substancjalna, którą „wydobywają” z potencjalności materii pierwszej, choć często tak jest — zwłaszcza w przypadku organizmów żywych, dających początek swoim potomkom. Może się jednak zdarzyć, że złożony zbiór przyczyn działający na szereg organizmów pozostających w relacji przodek-potomek, doprowadzi do „wyprowadzenia” z potencjalności materii pierwszej nowego rodzaju formy substancjalnej. Takie zdarzenie określilibyśmy mianem zmiany ewolucyjnej.

Tymczasem Lenartowicz odrzuca koncepcję „wydobywania” form substancjalnych z potencjalności materii twierdząc, że „ta teza wydaje się nie do utrzymania”. Dodaje przy tym, że „czynnik integrujący, ograniczający bardzo głęboko tę swobodę, jaką posiadają cząstki materii mineralnej, musi być pojmowany jako coś niepodzielnego". ${ }^{77}$ Jest nim, według niego, „żywa forma substancjalna”. ${ }^{78}$ Widać tu po raz kolejny tendencję Lenartowicza do hipostazowania formy substancjalnej, rozumianej jako odrębny (samodzielny?) byt, któremu przypisuje się właściwość bycia ożywionym. Co więcej, Lenartowicz mówi także o rozmnażaniu się formy substancjalnej, który to proces odróżnia od stworzenia jej prototypu z nicości (ex nihilo) przez Boga. ${ }^{79}$ Tezy te wydają się być problematyczne i radykalnie obce tradycji arystotelesowsko-tomistycznej. Le-

MASZ z Akwinu, Summa theologiae..., I, 2, 3 co.; I, 4, 1, ad 2; I, 84, 3, co.; III, 8, 3, co.; Summa contra gentiles..., II, 45.

\footnotetext{
${ }^{77}$ Lenartowicz, „Trzy koncepcje dynamiki biologicznej...”, s. 290 [wyróżnienie w oryginale].

${ }^{78}$ Lenartowicz, „Czy istnieją «dusze» roślin i zwierząt...”, s. 331.

${ }^{79}$ Por. Lenartowicz, „Czy istnieją «dusze» roślin i zwierząt...”, s. 335.
} 
nartowicz nie wyjaśnia, jak należy rozumieć rozmnażanie form substancjalnych, które według hylemorfizmu są zasadami metafizycznymi, a nie samodzielnymi bytami. Jego argument na rzecz stwarzania prototypów form substancjalnych bytów ożywionych ex nihilo, stoi w sprzeczności z główną tezą ewolucjonizmu rozumianego jako proces naturalny (niewykluczający, rzecz jasna, działania Boga — przeciwnie, pozostający wewnątrz rządów Boskiej opatrzności). ${ }^{80}$

\section{Podsumowanie}

Propozycja ontologii informacji biologicznej, zdefiniowanej za pomocą metafizycznych kategorii filozofii Arystotelesa, może się wydać anachronizmem. Współczesna biologia przejawia silną tendencję do traktowania dynamiki biologicznej jako przejawu (epifenomenu) fizyczno-chemicznego oddziaływania struktur. To w nich upatruje się źródło działania immanentnego bytów ożywionych. Wielu twierdzi, że wprowadzanie dodatkowej kategorii metafizycznej jest tu zbędne. A jednak pytanie o źródło strukturalizacji materii i kierunku dynamicznych oddziaływań pomiędzy jej częściami pozostaje. W tym kontekście, zasadna wydaje się uwaga Lenartowicza, który stwierdził:

Widzimy więc, że epigeneza, całościowość i niepodzielność, stanowiące problem biologiczno-filozoficzny od czasów starożytności, nie zdezaktualizowały się do dzisiaj. Przeciwnie, zjawiska te, jak się okazało z badań biochemicznych, przenikają cały organizm żywy na wszystkich jego poziomach organizacji i podczas wszystkich etapów jego egzystencji. Odkrycie DNA, jego zapisu symbolicznego i roli w produkcji enzymów, nie przyczyniło się do rozwiązania pytania postawionego przez Arystotelesa, ale przeciwnie, wagę tego pytania jeszcze bardziej podkreśliło. Mit samoreplikacji i mit kierowniczej roli DNA jest wynikiem dziwnej tendencji popularyzatorów, by nieproporcjonalnie podkreślać znaczenie uzyskanych odpowiedzi, przy równoczesnym lekceważeniu nowo powstałych zagadek. ${ }^{81}$

Należy w tym miejscu podkreślić, że szczególnego rodzaju formy substancjalne, jakimi są dusze wegetatywne bądź zmysłowe (dusze ludzkie stanowią odrębną kategorię) — podobnie do wszystkich innych form substancjalnych bytów przygodnych — są naturalnymi zasadami metafizycznymi, tzn. nie mają charakteru poza/nadnaturalnego (nadprzyrodzonego). Taki sam charakter ma także wewnętrzna celowość każdego bytu ożywionego (jak również nieożywionego). Jeśli życie jest istotnie fenomenem emergentnym, a nie tylko epifenomenem materii, wówczas kategorie przyczynowe zapropo-

\footnotetext{
${ }^{80}$ Kolejnym aspektem stanowiska Lenartowicza, który budzi wątpliwości, jest utożsamianie przezeń formy substancjalnej (duszy) oraz pojęcia entelechii z siłami witalnymi (witalizm) (por. LeNARTOwICZ, „Totipotencjalność...”, s.162-169). Kontrowersyjne wydaje się być także pełne entuzjazmu poparcie z jego strony teorii inteligentnego projektu (por. LenarTowicz, „Trzy koncepcje dynamiki biologicznej...”, s. 300302). Analiza tych zagadnień wykracza jednak poza ramy niniejszego artykułu.

${ }^{81}$ Lenartowicz, „Mitologia programu genetycznego DNA...”, s. 113.
} 
nowane przez Arystotelesa stają się intrygującą propozycją w próbie zrozumienia przy czynowości odgórnej postulowanej przez ontologiczny emergentyzm. ${ }^{82}$ Te same kategorie służą także jako podstawa ontologiczna dla omówionych w niniejszym artykule kluczowych aspektów informacji biologicznej.

\section{Mariusz Tabaczek}

\section{Bibliografia}

Adrianns Pieter, „Information”, w: Zalta (ed.), The Stanford Encyclopedia of Philosophy..., https://plato.stanford.edu/archives/fall2020/entries/information/ [08.10.2020].

Alexander Richard D., Darwinism and Human Affairs, University of Washington Press, Seattle 1979.

Allis C. David, Caparros Marie-Laure, Jenuwein Thomas, and Reinberg Danny (eds.) Epigenetics, 2nd ed., Cold Spring Harbor, New York 2015.

Arystoteles, Fizyka, przeł. Kazimierz Leśniak, Dzieła wszystkie, t. 2, Wydawnictwo Naukowe PWN, Warszawa 2003.

Arystoteles, Metafizyka, przeł. Kazimierz Leśniak, Dzieła wszystkie, t. 2, Wydawnictwo Naukowe PWN, Warszawa 2003.

Arystoteles, O częściach zwierząt, przeł. Paweł Siwek, Dzieła wszystkie, t. 3, Wydawnictwo Naukowe PWN, Warszawa 1992.

Arystoteles, O powstawaniu i niszczeniu, przeł. Kazimierz Leśniak, Dzieła wszystkie, t. 2, Wydawnictwo Naukowe PWN, Warszawa 2003.

Bar-Hillel Yehoshua and CARnap Rudolf, „Semantic Information”, British Journal for the Philosophy of Science 1953, vol. 14, no. 4, s. 147-157.

Barnes Gordon P., „The Paradoxes of Hylomorphism”, The Review of Metaphysics 2003, vol. 56, s. 501-523.

Bedau Mark, „Where's the Good in Teleology?”, Philosophy and Phenomenological Research 1992, vol. 52, s. 781-806.

Bergstrom Carl T. and Rosvall Martin, „The Transmission Sense of Information”, Biology and Philosophy 2011, vol. 26, no. 2, s. 159-176.

Boogerd Fred, Bruggeman Frank J., Hofmeyr Jan-Hendrik S., and Westerhoff Hans V. (eds.), Systems Biology: Philosophical Foundations, Elsevier, Amsterdam 2007.

Braillard Pierre-Alain and Malaterre Christophe (eds.), Explanation in Biology: An Enquiry into the Diversity of Explanatory Patterns in the Life Sciences, Springer, Dordrecht 2015.

\footnotetext{
${ }^{82}$ Por. TABACZeK, Emergence..., s. 248-256.
} 
Chodasewicz Krzysztof, Grabizna Adrianna, Proszewska Agnieszka, Stencel Adrian i Ziemny Aleksander (red.), Glówne problemy filozofii biologii, IFiS PAN, Warszawa 2017.

Craver Carl and Tabery James, „Mechanisms in Science”, w: Zalta (ed.) The Stanford Encyclopedia of Philosophy..., https://plato.stanford.edu/archives/spr2017/entries/science-mecha nisms/ [08.10.2020]

Craver Carl F. and Darden Lindley, In Search of Mechanisms: Discoveries across the Life Sciences, University of Chicago Press, Chicago 2013.

Cummins Robert, „Neo-Teleology”, w: Rosenberg and Arp (eds.), Philosophy of Biology..., s. $164-174$.

Dawkins Richard, Samolubny gen, przeł. Marek Skoneczny, Prószyński i S-ka, Warszawa 1996.

Deacon Terrence W., „Reciprocal Linkage Between Self-Organizing Processes Is Sufficient for Self-Reproduction and Evolvability”, Biological Theory 2006, vol. 1, s. 136-149.

DRETSKE Fred, Knowledge and the Flow of Information, The MIT Press, Cambridge 1981.

Fine Kit, „Things and Their Parts”, Midwest Studies in Philosophy 1999, vol. 23, s. 61-74.

Floridi Luciano, The Philosophy of Information, Oxford University Press, Oxford 2011.

Galilei Galileo, Il Saggiatore, Rome; The Assayer, trans. Stillman Drake and C.D. O'Malley, w: The Controversy on the Comets of 1618..., s. 151-336.

Godfrey-Smith Peter and Sterelny Kim, „Biological Information”, w: Zalta (ed.), The Stanford Encyclopedia of Philosophy (Summer 2016 Edition), https://plato.stanford.edu/archives/sum 2016/entries/information-biological/ [08.10.2020].

Godfrey-Smith Peter, „Genes and Codes: Lessons from the Philosophy of Mind?” w: HardCastle (ed.), Where Biology Meets Psychology..., s. 305-331.

Gotтhelf Allan, Teleology, First Principles, and Scientific Method in Aristotle's Biology, Oxford University Press, Oxford 2012.

Green Sara, „Philosophy of Systems and Synthetic Biology”, w: Zalta (ed.), The Stanford Encyclopedia of Philosophy..., https://plato.stanford.edu/archives/win2017/entries/systems-synthe tic-biology/ [08.10.2020].

Green Sara (ed.), Philosophy of Systems Biology: Perspectives from Scientists and Philosophers, Springer, Copenhagen 2017.

Griffiths Paul E. and Gray Russell D., „Developmental Systems and Evolutionary Explanation”, Journal of Philosophy 1994, vol. 91, no. 6, s. 277-304.

Griffiths Paul E. and Neumann-Held Eva M., „The Many Faces of the Gene”, BioScience 1999, vol. 49 , no. 8 , s. 656-662.

Hamilton W., „The Genetical Evolution of Social Behaviour I-II”, Journal of Theoretical Biology 1964, vol. 7, no. 1, s. 1-52.

Hardcastle Valerie (ed.), Where Biology Meets Psychology: Philosophical Essays, MIT Press, Cambridge 1999. 
Helanterä Heikki and Uller Tobias, „The Price Equation and Extended Inheritance”, Philosophy and Theory in Biology 2010, vol. 2, no. 1, s. 1-17.

Heller Michał, Lubański Mieczysław i Ślaga Szczepan W., Zagadnienia filozoficzne wspólczesnej nauki, wyd. 4, Akademia Teologii Katolickiej, Warszawa 1997.

HINTIKKA Jaakko, Knowledge and Belief: An Introduction to the Logic of the Two Notions, Cornell University Press, Ithaca 1962.

Hume David, Badania dotyczące rozumu ludzkiego, przel. Dawid Misztal i Tomasz Sieczkowski, Wielkie dzieła filozoficzne, Zielona Sowa, Warszawa 2005.

JablonKA Eva, „Genes as Followers in Evolution - A Post-Synthesis Synthesis?”, Biology and Philosophy 2010, vol. 21, no. 1, s. 143-154.

Jablonka Eva and Lamb Marion J., Evolution in Four Dimensions, MIT Press, Cambridge, Massachusetts 2005

JADACKI Jacek Juliusz (red.), Analiza pojęcia informacji, Wydawnictwo Naukowe Semper, Warszawa 2003.

Jaworski William, Structure and the Metaphysics of Mind: How Hylomorphism Solves the Mind-Body Problem, Oxford University Press, Oxford 2016.

Johnson Monte R., Aristotle on Teleology, Clarendon Press, Oxford 2005.

JoHnsтоN Mark, „Hylomorphism”, Journal of Philosophy 2006, vol. 103, no. 12, s. 652-698.

Kiм Jaegwon, „Supervenience as a Philosophical Concept”, Metaphilosophy 1990, vol. 21, no. $1-2$, s. $1-27$

KоsцICKI Kathrin, The Structure of Objects, Oxford University Press, Oxford 2010.

Koszteyn Jolanta (red.), Vivere et Intelligere. Wybrane prace Piotra Lenartowicza SJ wydane z okazji 75-lecia jego urodzin, WAM, Kraków 2009.

KüPPERS Bernd-Olaf, Geneza informacji biologicznej. Filozoficzne problemy powstania życia, przeł. Włodzimierz Ługowski, PWN, Warszawa 1991.

LAtawiec Anna i in. (red.), Filozoficzne i naukowo-przyrodnicze elementy obrazu Świata, vol. 1-8, Wydawnictwo ATK, Warszawa 1996-2010.

LeHRER Jonah, Proust Was a Neuroscientist, Houghton Mifflin Company, Boston, New York 2007.

Lenartowicz Piotr, „Czy istnieją «dusze» roślin i zwierząt, a jeśli tak, to skąd się one biorą?”, w: Koszteyn (red.), Vivere et Intelligere..., s. 317-336.

Lenartowicz Piotr, „Mitologia programu genetycznego DNA”, w: Koszteyn (red.), Vivere et Intelligere..., s. 101-114.

Lenartowicz Piotr, „Sens i zakres pojęcia informacji genetycznej”, w: Koszteyn (red.), Vivere et Intelligere..., s. 133-144.

Lenartowicz Piotr, „Struktura bytu żywego w arystotelizmie”, w: Koszteyn (red.), Vivere et Intelligere..., s. 355-379. 
Lenartowicz Piotr, „Totipotencjalność - kluczowe pojęcie biologii rozwoju”, w: Koszteyn (red.), Vivere et Intelligere..., s. 145-171.

Lenartowicz Piotr, „Trzy koncepcje dynamiki biologicznej: Arystotelesowska, neo-darwinowska, inteligentnego projektu”, w: KosZteYN (red.), Vivere et Intelligere..., s. 285-303.

Lenartowicz Piotr, „Wyjściowe przesłanki teorii życia biologicznego”, w: Koszteyn (red.), Vivere et Intelligere..., s. 305-315.

Lenartowicz Piotr and Koszteyn Jolanta, Wprowadzenie do zagadnień filozoficznych, WAM, Kraków 2000.

Lewontin Richard and Levins Richard, Biology Under the Influence: Dialectical Essays on the Coevolution of Nature and Society, NYU Press, New York 2007.

Lewontin Richard, It Ain't Necessarily So: The Dream of the Human Genome and Other Illusions, New York Review Books, New York 2001.

LOCKE John, Rozważania dotyczące rozumu ludzkiego, przeł. Bolesław J. Gawecki, Biblioteka Klasyków Filozofii, Państwowe Wydawnictwo Naukowe, Warszawa 1955, I, 4, 25.

Lowe E.J., „A Neo-Aristotelian Substance Ontology: Neither Relational nor Constituent”, w: ТАнко (ed.), Contemporary Aristotelian Metaphysics..., s. 229-248.

Lubański Mieczysław, „O pojęciu informacji”, Studia Philosophiae Christianae 1974, t. 10, nr 1, s. 73-99.

Machamer Peter, Darden Lindley, and Craver Carl F., „Thinking about Mechanisms”, Philosophy of Science 2013, vol. 67, s. 1-25.

Marek-Bieniasz Anna, „Genocentryczny paradygmat rozumienia przyrody i jego zasadność w R. Dawkinsa interpretacji ewolucji”, Studia Philosophiae Christianae 2009, t. 45, nr 1, s. 163 178.

Marmodoro Anna „Aristotle's Hylomorphism Without Reconditioning”, Philosophical Inquiry 2013, vol. 37, s. 5-22.

Mazierski Stanisław (red.), Zarys filozofii przyrody ożywionej, KUL, Lublin 1980.

Mekios Constantinos, „Explanation in Systems Biology: Is It All About Mechanisms?”, w: Braillard and Malaterre (eds.), Explanation in Biology..., s. 47-72.

МiкuŁowsкi-Ромовsкі Jerzy, Informacja i komunikacja: pojęcia, wzajemne relacje, Zakład Narodowy im. Ossolińskich, Wrocław 1988.

NAWRoCKI Witold, „W poszukiwaniu istoty informacji”, w: JADACKI (red.), Analiza pojęcia informacji..., s. 37-62.

NovotnÝ Daniel D. and NovÁK Lukáš (eds.), Neo-Aristotelian Perspectives in Metaphysics, Routledge, New York 2014.

Oyama Susan, „Causal Democracy and Causal Contributions in Developmental Systems Theory", Philosophy of Science 2000, vol. 67, s. S332-S347. 
Oyama Susan, Griffiths Paul E., and Gray Richard D. (eds.), Cycles of Contingency: Developmental Systems and Evolution, The MIT Press, Cambridge, Massachusetts 2001.

Oyama Susan, Griffiths Paul E., and Gray Russell D., „Introduction: What Is Developmental Systems Theory?”, w: Oyama, Griffiths, and Gray (eds.), Cycles of Contingency..., s. 1-12.

Oyama Susan, The Ontogeny of Information, Duke University Press, Durham 1985.

Paro Renato, Grossniklaus Ueli, Santoro Raffaella, and Wutz Anton, Introduction to Epigenetics, Springer, Berlin 2021.

Perlman Mark, „The Modern Philosophical Resurrection of Teleology”, w: Rosenberg and ArP (eds.), Philosophy of Biology..., s. 149-163.

Putnam Hilary, Mind, Language and Reality: Philosophical Papers, Cambridge University Press, Cambridge 1975.

RoBert Jason S., „Developmental Systems and Animal Behaviour”, Biology and Philosophy 2003, vol. 18, s. 477-489.

Robert Jason S., „How Developmental Is Evolutionary Developmental Biology?”, Biology and Philosophy 2002, vol. 17, s. 591-611.

Rosenberg Alex and Arp Robert (eds.), Philosophy of Biology: An Anthology, Blackwell, Oxford 2010 .

Ruse Michael (ed.), The Oxford Handbook of Philosophy of Biology, Oxford University Press, Oxford, New York 2008.

Shoemaker Sydney, „Kim on Emergence”, Philosophical Studies 2002, vol. 108, s. 53-63.

SIEDLIŃSKi Radosław, „Genocentryzm versus teoria systemów rozwojowych. Dwa konkurencyjne sposoby rozumienia informacji w biologii współczesnej”, Semina Scientiarum 2018, t. 16, s. 67 93.

Simpson William M.R., Koons Robert C., and OrR James (eds.), Neo-Aristotelian Metaphysics and the Theology of Nature, Routledge, New York 2021.

Simpson William M.R., Koons Robert C., and Teh Nicholas J. (eds.), Neo-Aristotelian Perspectives on Contemporary Science, Routledge, New York 2018.

Sterelny Kim, Smith Kelly C., and Dickson Michael, „The Extended Replicator”, Biology and Philosophy 1996, vol. 11, s. 377-403.

TABAczek Mariusz, Emergence: Towards A New Metaphysics and Philosophy of Science, University of Notre Dame Press, Notre Dame 2019.

Tанко Tuomas E. (ed.), Contemporary Aristotelian Metaphysics, Cambridge University Press, Cambridge 2011.

TемРсzук Michał, Ontologia świata przyrody, Universitas, Kraków 2005.

The Controversy on the Comets of 1618, University of Pennsylvania Press, Philadelphia 1960.

Tomasz z Aкwinu, Summa contra gentiles, https://tiny.pl/9118g [08.10.2020]. 
Tomasz z Akwinu, Summa theologiae, https://tiny.pl/9118g [08.10.2020].

Verschuuren Gerard M., Aquinas and Modern Science: A New Synthesis of Faith and Reason, Angelico Press, Kettering 2016.

Vort Eberhad O., A First Course in Systems Biology, Garland Science, New York and London 2013.

Walsh Denis M. „Teleology”, w: Ruse (ed.), The Oxford Handbook of Philosophy of Biology..., s. 113-137.

WierzBicki Andrzej T., „Dziedziczenie epigenetyczne”, Kosmos 2004, t. 53, nr 3-4, s. 271-280.

Williams George C., Adaptation and Natural Selection, Princeton University Press, Princeton 1966.

Williams George C., „The Question of Adaptive Sex Ratio in Outcrossed Vertebrates”, Proceedings of the Royal Society of London B 1979, vol. 205, s. 567-580.

Wojciechowski Tadeusz, Teoria hylemorfizmu w ujęciu autorów neoscholastycznych, ATK, Warszawa 1967.

WoJCIEChOwsкi Tadeusz, Zarys filozofii przyrody ożywionej, Wydział Teologiczny Uniwersytetu Opolskiego, Opole 1997.

Wright Larry, „Functions”, The Philosophical Review, 1973, vol. 82, s. 139-168.

Zalta Edward N. (ed.) The Stanford Encyclopedia of Philosophy (Spring 2017 Edition).

Zalta Edward N. (ed.), The Stanford Encyclopedia of Philosophy (Fall 2020 Edition).

Zalta Edward N. (ed.), The Stanford Encyclopedia of Philosophy (Summer 2016 Edition).

Zalta Edward N. (ed.), The Stanford Encyclopedia of Philosophy (Winter 2017 Edition).

Ziemny Aleksander, „Natura dziedziczenia”, w: Chodasewicz, Grabizna, Proszewska, Stencel i ZIEMnY (red.), Glówne problemy filozofii biologii..., s. 84-87.

ZIEMnY Aleksander, „Spór o genocentryzm w filozofii biologii”, Studia Philosophiae Christianae 2017, t. 53, nr 1, s. 146-168.

\section{Aktualność arystotelizmu w kontekście poszukiwań ontologicznego fundamentu informacji biologicznej}

\section{Streszczenie}

Pomimo trudności w sformułowaniu jednoznacznie uzgodnionej i ściśle naukowej definicji informacji, w tym także informacji biologicznej, niebywały sukces paradygmatu i metodologii biologii molekularnej i genetyki, doprowadził do genocentryzmu, który podniósł geny (rozumiane jako nośniki informacji biologicznej) do rangi podstawowych jednostek biologicznych, podlegających działaniu doboru naturalnego i ewolucji. Artykuł ukazuje drogę od zakwestionowania genocentryzmu do wieloaspektowego ujęcia informacji biologicznej, na tle historycznego rozwoju oraz aktualnego stanu badań filozoficznych nad istotą informacji w ujęciu ogólnym. W odniesieniu do ontycznego wymiaru informacji biologicznej, zostaje przedstawiony argument na 
rzecz aktualności kluczowych kategorii filozofii przyrody Arystotelesa jako fundamentalnych dla rozumienia i definiowania najważniejszych aspektów informacji zapisanej i znajdującej wyraz w funkcjonowaniu systemów (bytów) ożywionych.

Slowa kluczowe: Arystoteles, biologia systemów, genocentryzm, hylemorfizm, informacja biologiczna, kontekstualizacja DNA, ontologia informacji, systemowa teoria rozwoju, teleologia.

\section{Timeliness of Aristotelianism in the Context of the Search for the Ontological Foundation of Biological Information}

\section{Summary}

Despite difficulties in formulating an unambiguously agreed and strictly scientific definition of information, including biological information, the remarkable success of the paradigm and methodology of molecular biology and genetics led to genocentrism, which elevated genes (understood as carriers of biological information) to the rank of basic biological entities, subject to natural selection and evolution. The article shows the way from questioning genocentrism to a multi-faceted approach to biological information, against the background of historical development and the current state of philosophical research on the essence of information in general. In reference to the ontological dimension of biological information, an argument is presented in favor of the timeliness of the key categories of Aristotle's philosophy of nature as fundamental for understanding and defining the most important aspects of information stored and expressed in the functioning of living systems (beings).

Keywords: Aristotle, biological information, contextualization of DNA, developmental system theory, genocentrism, hylomorphism, ontology of information, systems biology, teleology. 